\title{
Temperature and precipitation signal in two Alpine ice cores over the period 1961-2001
}

\author{
I. Mariani ${ }^{1,2}$, A. Eichler ${ }^{1,2}$, T. M. Jenk ${ }^{1,2}$, S. Brönnimann ${ }^{2,3}$, R. Auchmann ${ }^{2,3}$, M. C. Leuenberger ${ }^{2,4}$, and \\ M. Schwikowski ${ }^{1,2,5}$ \\ ${ }^{1}$ Paul Scherrer Institute, Villigen, Switzerland \\ ${ }^{2}$ Oeschger Centre for Climate Change Research, University of Bern, Bern, Switzerland \\ ${ }^{3}$ Institute of Geography, University of Bern, Bern, Switzerland \\ ${ }^{4}$ Physics Institute, University of Bern, Bern, Switzerland \\ ${ }^{5}$ Department of Chemistry and Biochemistry, University of Bern, Bern, Switzerland \\ Correspondence to: M. Schwikowski (margit.schwikowski@psi.ch)
}

Received: 12 November 2012 - Published in Clim. Past Discuss.: 29 November 2012

Revised: 11 December 2013 - Accepted: 25 April 2014 - Published: 4 June 2014

\begin{abstract}
Water stable isotope ratios and net snow accumulation in ice cores are commonly interpreted as temperature or precipitation proxies. However, only in a few cases has a direct calibration with instrumental data been attempted. In this study we took advantage of the dense network of observations in the European Alpine region to rigorously test the relationship of the annual and seasonal resolved proxy data from two highly resolved ice cores with local temperature and precipitation. We focused on the time period 1961-2001 with the highest amount and quality of meteorological data and the minimal uncertainty in ice core dating ( \pm 1 year). The two ice cores were retrieved from the Fiescherhorn glacier (northern Alps, $3900 \mathrm{~m}$ a.s.1.), and Grenzgletscher (southern Alps, $4200 \mathrm{~m}$ a.s.l.). A parallel core from the Fiescherhorn glacier allowed assessing the reproducibility of the ice core proxy data. Due to the orographic barrier, the two flanks of the Alpine chain are affected by distinct patterns of precipitation. The different location of the two glaciers therefore offers a unique opportunity to test whether such a specific setting is reflected in the proxy data. On a seasonal scale a high fraction of $\delta^{18} \mathrm{O}$ variability was explained by the seasonal cycle of temperature $(\sim 60 \%$ for the ice cores, $\sim 70 \%$ for the nearby stations of the Global Network of Isotopes in Precipitation - GNIP). When the seasonality is removed, the correlations decrease for all sites, indicating that factors other than temperature such as changing moisture sources and/or precipitation regimes affect the isotopic signal on this timescale. Post-depositional phenomena may
\end{abstract}

additionally modify the ice core data. On an annual scale, the $\delta^{18} \mathrm{O} /$ temperature relationship was significant at the $\mathrm{Fi}$ escherhorn, whereas for Grenzgletscher this was the case only when weighting the temperature with precipitation. In both cases the fraction of interannual temperature variability explained was $\sim 20 \%$, comparable to the values obtained from the GNIP stations data. Consistently with previous studies, we found an altitude effect for the $\delta^{18} \mathrm{O}$ of $-0.17 \% / 100 \mathrm{~m}$ for an extended elevation range combining data of the two ice core sites and four GNIP stations. Significant correlations between net accumulation and precipitation were observed for Grenzgletscher during the entire period of investigation, whereas for Fiescherhorn this was the case only for the less recent period (1961-1977). Local phenomena, probably related to wind, seem to partly disturb the Fiescherhorn accumulation record. Spatial correlation analysis shows the two glaciers to be influenced by different precipitation regimes, with the Grenzgletscher reflecting the characteristic precipitation regime south of the Alps and the Fiescherhorn accumulation showing a pattern more closely linked to northern Alpine stations. 


\section{Introduction}

The stable isotopes ratios in meteoric water $\left({ }^{18} \mathrm{O} /{ }^{16} \mathrm{O}\right.$ and, similarly ${ }^{2} \mathrm{H} /{ }^{1} \mathrm{H}$, not discussed in this paper) are widely used as temperature proxies (Craig, 1961; Dansgaard, 1964). Commonly these ratios are reported in the delta notation $\left(\delta^{18} \mathrm{O}\right.$ and $\delta^{2} \mathrm{H}$ or $\left.\delta \mathrm{D}\right)$ with $\delta$ denoting the deviation from an international reference standard (e.g. VSMOW, Vienna Standard Mean Ocean Water) in per mil (\%o).

To a first approximation, $\delta^{18} \mathrm{O}$ in meteoric water can be considered as a proxy for the condensation temperature in the cloud with its variation within the water cycle described by the Rayleigh distillation model. The heavy isotopologues preferentially condense with respect to the lighter ones and progressive distillation occurs as the air mass loses moisture through precipitation (Dansgaard, 1964). The primary microphysical processes affecting this proxy within the water cycle (equilibrium and non-equilibrium fractionations) are known and can be quantified (Dansgaard, 1964; Jouzel and Merlivat, 1984; Ciais and Jouzel, 1994; Gat, 1996; Araguás-Araguás et al., 2000). However, several factors may change the isotopic signal before, during and after the precipitation event. For instance, subcloud processes such as exchange and reevaporation may lead to additional fractionation, leaving an imprint in both raindrops and remaining vapour (Friedman et al., 1962; Risi et al., 2008; Field et al., 2010).These secondary processes however do not affect solid precipitation in the form of snow (Friedman et al., 1962; Field et al., 2010).

Besides the microphysical processes, changes of the moisture sources may additionally affect the isotopic signal (Rozanski et al., 1993). Precipitation intermittency (Casado et al., 2013) or seasonality (Perrson et al., 2011) may bias the $\delta^{18} \mathrm{O}$ toward the season with more precipitation. In this case the $\delta^{18} \mathrm{O}$ should be associated with the precipitationweighted temperature rather than the mean temperature (Jouzel et al., 1997a; Kohn and Welker, 2005; Sturm et al., 2010). The interpretation of the $\delta^{18} \mathrm{O}$ signal in natural archives may be further complicated in the case of ice cores, where post-depositional processes can lead to signal alteration (e.g. Stichler and Schotterer, 2000; Schotterer et al., 2004). These processes may involve melting and refreezing (Jouzel and Souchez, 1982), diffusion (Johnsen, 1977; Johnsen et al., 2000), snow removal by winds (Wagenbach et al., 1988; Schoener et al., 2002) and sublimation (Stichler et al., 2001).

In order to understand such a complex signal the $\delta^{18} \mathrm{O}$ in precipitation can be investigated following different approaches: using (i) observational data from global precipitation collection networks such as the GNIP data set (IAEA/WMO, 2013), enabling $\delta^{18} \mathrm{O} /$ temperature $\left(\delta^{18} \mathrm{O} / T\right)$ calibrations for different regions in the world (Yurtsever and Gat, 1981; Rozanski et al., 1992, 1993), (ii) natural archives such as ice cores, tree rings and lake sediments (e.g. Bradley, 1999) which allow access to records exceeding the period of direct instrumental measurements, (iii) models to investigate the underlying physical processes such as simple Rayleigh distillation models (e.g. Jouzel et al., 1997b) or more complex atmospheric general circulation models (GCMs) making it possible to track the water throughout the hydrological cycle, accounting also for other processes such as changing moisture sources, evaporation, and interaction with subcloud water (e.g. Ciais and Jouzel, 1994; Jouzel et al., 2000; Jouzel, 2003; Noone and Sturm, 2010). Meanwhile, several isotopeequipped GCMs are available and their output has recently been investigated through the Stable Water Isotope Intercomparison Group (SWING2) experiment (Sturm et al., 2010; Conroy et al., 2013).

In the European Alpine region and specifically in the Swiss area investigated in this study, the interpretation of the isotopic signal is particularly challenging due to a distinct topography, with the Alps acting as a divide between the Mediterranean and the European continental climate (Barry, 2008). The northern Alps are dominated by the influence of North Atlantic air masses in winter and land evaporation in summer whereas the southern Alps are characterized by higher intraseasonal precipitation variability and substantial contribution from the Mediterranean, especially in spring and autumn (Frei and Schär, 1998; Eichler et al., 2004; Sodemann and Zubler, 2009).

Common features in precipitation may be observed in winter under the influence of mid-latitude cyclones arriving from the North Atlantic by means of intensified westerlies. Systems advected from the north or the south are also frequent (see e.g. Eichler et al., 2004; Barry, 2008). In this case, precipitation affects especially one flank, often accompanied by Foehn situations on the other side. In winter the prevailing directions of the cyclones are from the northern and western quadrants. As a consequence, orographic precipitation over the northern Alps and consequently Foehn over the southern Alps is a common phenomenon. Similarly, atmospheric disturbances arriving from the southern quadrants especially in spring and autumn generate Foehn situations over the northern Alps (Barry, 2008). It is nonetheless known that Foehn events are not always associated with precipitation over the other flank, as shown in Seibert (1990). Convective systems contribute to the whole region's precipitation as well, especially in summer (Frei and Schär, 1998; Eichler et al., 2004; Barry, 2008; Sodemann and Zubler, 2009). The resulting climatology is such that in general there is more precipitation over the southern Alps, peaking in spring and autumn, and less precipitation over the northern Alps, with a large maximum in summer (Frei and Schär, 1998; Eichler et al., 2004; Sodemann and Zubler, 2009).

Neither GCMs or higher-resolved regional models are able to spatially resolve the Alpine subregions affected by their characteristic precipitation regimes. However, an extended monitoring network exists over this area, and several studies have been conducted for the time for which instrumental records are available (Siegenthaler and Oeschger, 1980; Rozanski et al., 1992; Schürch et al., 2003). The 
relation between altitude and change of the isotopic value as well as the $\delta^{18} \mathrm{O} / T$ relation has been quantified, using the $\delta^{18} \mathrm{O}$ data of the GNIP station network. A lapse rate of $\sim-0.2 \% / 100 \mathrm{~m}$ was obtained (Siegenthaler and Oeschger, 1980; Schürch et al., 2003) and generally higher long-term slopes compared to the rest of Europe were found (Rozanski et al., 1992). Because of the changes in moisture sources, the intraseasonal variability of precipitation is relatively high, especially on the southern side where a mixture of sources originating from the North Atlantic Ocean, the Mediterranean region, the North Sea and Baltic Sea as well as from European land surface re-evaporation contribute to the total annual precipitation of a specific site (Sodemann and Zubler, 2009) and may thus significantly affect the $\delta^{18} \mathrm{O}$ signal. Such an influence of changes in large-scale circulation patterns was observed in Alpine tree rings (Saurer et al., 2012).

There is large potential offered by Alpine ice cores in terms of reconstructing past changes in the climate and the hydrological cycle, but a better understanding of the signal deposited on the glacier is needed. Some studies which combine instrumental and Alpine ice core data are available (e.g. Rozanski et al., 1997; Schotterer et al., 1997; Eichler et al., 2001; Sigl, 2009; Bohleber et al., 2013). Ice cores extracted from the Alps proved to be valuable tools for the reconstruction of atmospheric pollutants and studies of their transport (e.g. Wagenbach et al., 1988; Schwikowski et al., 1999, 2004). However, as mentioned before, the interpretation of the isotopic signal is not straightforward. $\delta^{18} \mathrm{O}$ records a signal only when snowfall occurs (Jouzel et al., 1997a; Sturm et al., 2010) and seasonality of precipitation and postdepositional effects can be very local phenomena, causing each high-altitude site to behave uniquely. Investigating the precipitation climatology near the glacier can thus provide fundamental information about the proxy deposition. Using the data from the Grenzgletscher ice core (also investigated in this study) Brönnimann et al. (2013) addressed the problem of irregular sampling of weather events by natural archives. A simple forward model was developed to replicate the ice core on a sample-by-sample basis from daily meteorological data, which well reproduced accumulation and $\delta^{18} \mathrm{O}$ variations on a sub-seasonal scale over the most recent 15 years of the ice core record. The uncertainties induced by irregular sampling in the relation between ice core proxies and mean climate were investigated with a new reconstruction method, a Monte Carlo re-sampling approach of long meteorological records. Low correlations between annual mean temperature and precipitation-weighted temperature were obtained, as a given combination of $\delta^{18} \mathrm{O}$ and accumulation can be achieved in many different ways.

As well as $\delta^{18} \mathrm{O}$-derived temperatures, reconstructions of past accumulation rates from mountain glaciers are also available (Henderson et al., 2006; Schwerzmann et al., 2006; Herren et al., 2013). The reconstructed net accumulation can be regarded as precipitation proxy, with three caveats: (i) in order to account for thinning effects, such reconstructions require an accurate description of the glacier ice flow by means of physical models; (ii) the glacier only records the net balance between what was deposited and what was removed during the year, e.g. by partial melting, wind erosion or sublimation; (iii) precipitation at high altitudes can be a very local phenomenon. In a region such as the Alps, characterized by high temporal and spatial variability of the climatic parameters, the interpretation of the net snow accumulation rate as a proxy for regional precipitation might thus be limited even in the case of negligible post-depositional effects.

In this study we focus on annually and sub-annually resolved records of $\delta^{18} \mathrm{O}$ and net accumulation from two highly resolved ice cores from the northern and the southern Alps, in order to investigate whether and how the temperature and precipitation signals are captured at these sites, with the final goal of improving the understanding of the ice core proxies $\delta^{18} \mathrm{O}$ and net accumulation. We take advantage of the unique opportunity offered by the dense observation station network over this region. For this detailed study, we focus on the most recent decades (1961-2001), where the amount and quality of the available instrumental data is highest and the dating uncertainty in the ice cores is minimal. In Sect. 2 the data sets are described. The analysis of the $\delta^{18} \mathrm{O} /$ temperature and the accumulation/precipitation relationship is discussed in Sect. 3 and conclusions and implications are presented in Sect. 4.

\section{Data}

\subsection{Ice core sites}

In this study we investigate two Alpine ice cores, one from the northern Alps (Fiescherhorn, FH) and the other from the southern Alps (Grenzgletscher, GG) (see Fig. 1). From the Fiescherhorn glacier several ice cores have been collected (Schotterer et al., 1997, 2002; Schwikowski et al., 1999; Jenk, 2006). Here we mainly focus on the records from the core extracted in December 2002, reaching bedrock at a depth of $151 \mathrm{~m}\left(46^{\circ} 33^{\prime} 3.2^{\prime \prime} \mathrm{N}, 8^{\circ} 04^{\prime} 0.4^{\prime \prime} \mathrm{E}, 3900 \mathrm{~m}\right.$ a.s.l., Jenk, 2006). Additionally, the results from the core recovered in 1989 are used to assess the reproducibility of the records $\left(46^{\circ} 33^{\prime} 6.28^{\prime \prime} \mathrm{N}, 8^{\circ} 04^{\prime} 4.02^{\prime \prime}\right.$ E, $3900 \mathrm{~m}$ a.s.l., Schotterer et al., 1997; Schwikowski et al., 1999). The two drilling sites are $100 \mathrm{~m}$ apart on an extended relatively flat accumulation area with a steep cliff to the north. The ice core from Grenzgletscher in the southern Alps (Monte Rosa massif, $45^{\circ} 55^{\prime} 28^{\prime \prime} \mathrm{N}, 7^{\circ} 52^{\prime} 3^{\prime \prime} \mathrm{E}, 4200 \mathrm{~m}$ a.s.1.) was extracted in October 1994, reaching a depth of $125 \mathrm{~m}$ (Eichler et al., 2000, 2001). The drilling site is located in the accumulation area downstream of the Colle Gnifetti saddle, were many other ice core studies were conducted (e.g. Schotterer et al., 1985; Wagenbach et al., 1988; Schwikowski et al., 2004). 


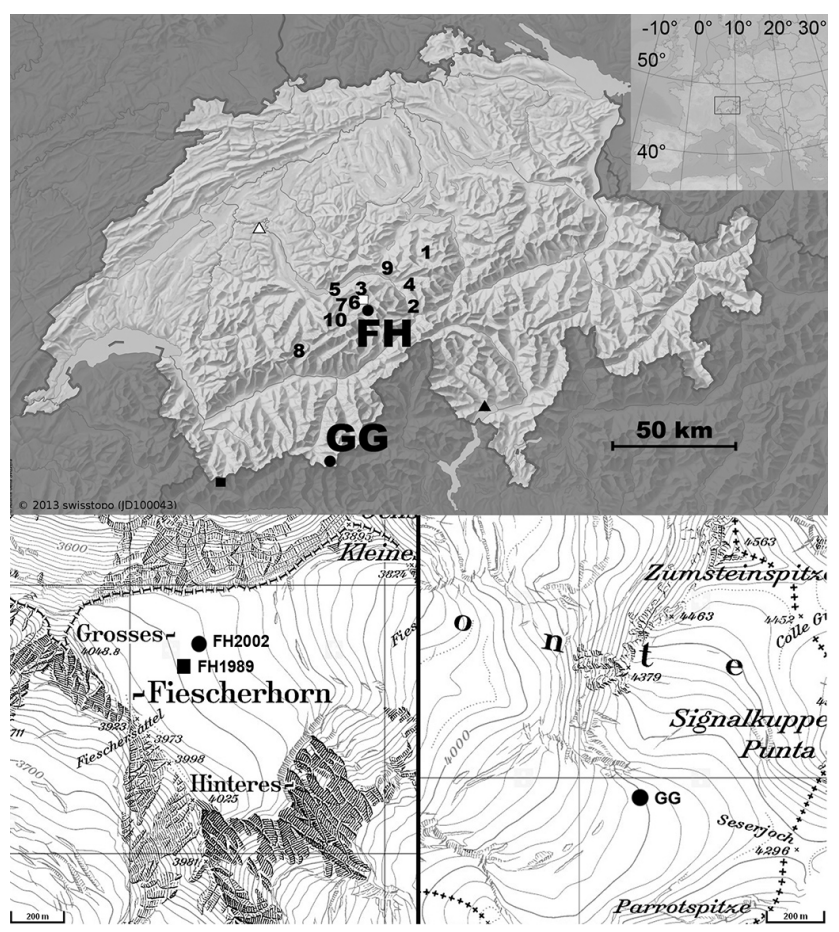

Figure 1. Upper panel: topographic map of Switzerland showing the position of the two glaciers (black dots), Fiescherhorn (FH), and Grenzgletscher (GG) (source: Atlas of Switzerland, http: //www.atlasderschweiz.ch/), together with the location of Switzerland in Europe (insert). The numbers indicate the weather stations near the Fiescherhorn, as listed in Table 2. Engelberg (1), Grimsel Hospiz (2), Grindelwald (3), Guttannen (4), Interlaken (5), Kleine Scheidegg (6), Lauterbrunnen (7), Leukerbad (8), Meiringen (9), Mürren (10). Squares indicate the location of the Jungfraujoch (white) and Grand Saint Bernard (black) weather stations and the triangle the position of the low-altitude stations Bern (white) and Locarno (black). Lower panels: topographic map of the ice core drilling sites (source: Swisstopo, http://map.geo.admin.ch/). The left panel shows the location of the FH1989 and FH2002, the right panel shows the position of the Grenzgletscher drilling site (GG).

\subsubsection{Dating of the ice cores}

The dating of the ice cores was established with a multiparametric approach involving:

- Annual layer counting of the seasonally varying signals, like $\delta^{18} \mathrm{O}$ (see Fig. 2) and concentration of $\mathrm{NH}_{4}^{+}$, whose maxima correspond to summer and minima to winter (Schwikowski et al., 1999).

- Horizons indicated by spikes in the records of chemical species which correspond to well documented events: e.g. the $\mathrm{Ca}^{2+}$ maximum in 2000, 1990, 1977 as a tracer for a prominent Saharan dust fall (Schwikowski et al., 1995; Jenk, 2006) (triangles in Fig. 2), ${ }^{137} \mathrm{Cs}$ for the Chernobyl accident in 1986 (Schwikowski et al., 1999; Eichler et al., 2000) (circles in Fig. 2), ${ }^{3} \mathrm{H}$ with a peak
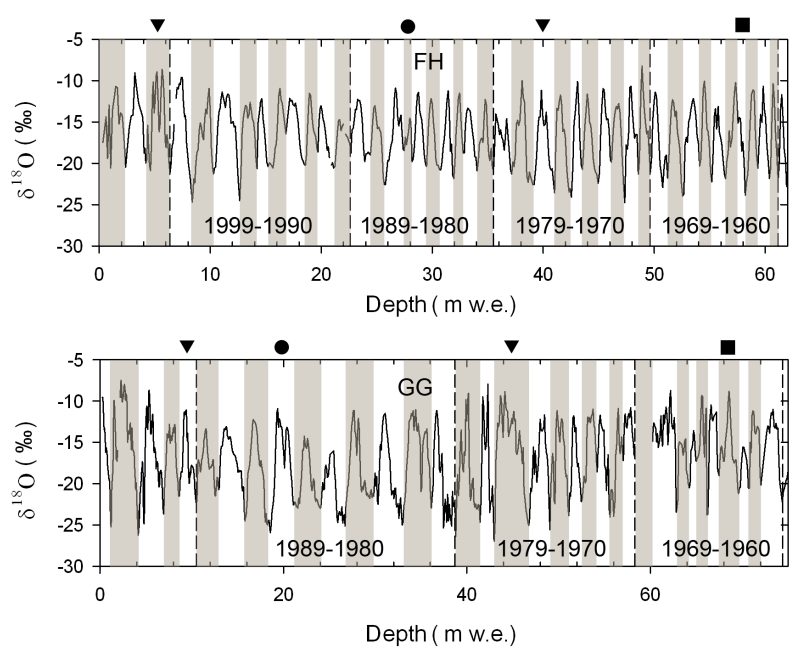

Figure 2. $\delta^{18} \mathrm{O}$ raw data from Fiescherhorn core drilled in 2002 (FH, top panel, first $60 \mathrm{~m}$ w.e. corresponding to the period 19612001), and Grenzgletscher (GG, bottom panel, first $70 \mathrm{~m}$ w.e., corresponding to the period 1961-1993, with a gap in the period 19681970). White and grey alternating bars show the different annual layers. The reference horizons used for the dating are indicated as follows. Triangles: Saharan dust events (2000, 1990, 1977). Circles: Chernobyl accident in 1986. Squares: tritium peak in 1963. The stratigraphy of FH1989 was extensively described in Schotterer et al. (1997) and Schwikowski et al. (1999).

in 1963 from thermonuclear bomb tests (Schwikowski et al., 1999; Eichler et al., 2000; Jenk, 2006) (squares in Fig. 2).

- Nuclear dating using ${ }^{210} \mathrm{~Pb}$ (Eichler et al., 2000).

Due to the presence of stratigraphic markers and wellpreserved $\delta^{18} \mathrm{O}$ seasonality (see Fig. 3 and Sect. 3.1.1) the resulting dating uncertainty for the period considered in this study is \pm 1 year for both ice cores. This value was empirically estimated as the number of ambiguous annual layers that were attributed between the reference horizons. The Fiescherhorn core covers the time period of $\sim$ AD 16802002 and the Grenzgletscher core the period of AD 19371994. The latter has a gap in the data for the time period 1968-1970, due to bad core quality and a failure in the cooling system of the cold room with consequent melting of the corresponding ice core sections (Eichler et al., 2000). The FH1989 covers the period AD 1946-1989; for further details see Schotterer et al. (1997) and Schwikowski et al. (1999).

\subsubsection{Ice core $\delta^{18} \mathrm{O}$ data}

The $\delta^{18} \mathrm{O}$ in both ice cores was measured by Isotope Ratio Mass Spectrometry (IRMS) after $\mathrm{CO}_{2}$ equilibration by the Climate and Environmental Physics group at the University of Bern, Switzerland for the Fiescherhorn (Jenk, 2006) and at the Paul Scherrer Institute, Switzerland for the 


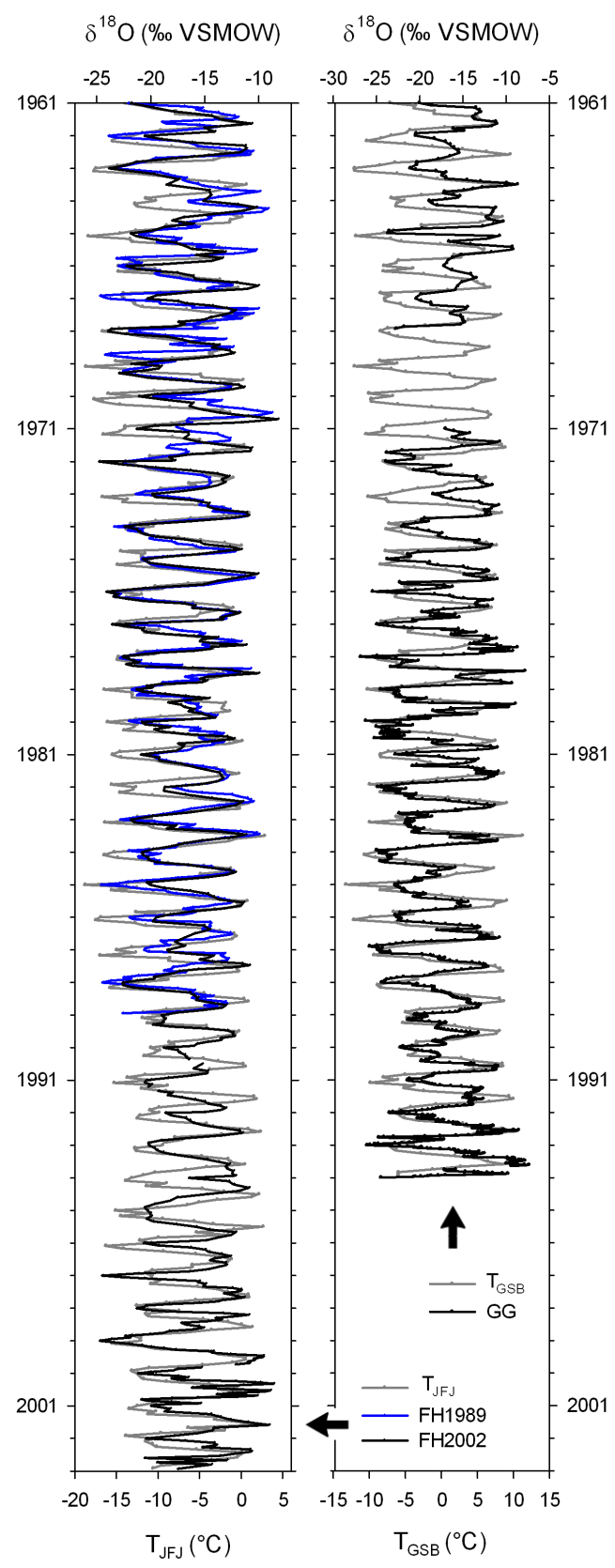

Figure 3. Left panel: $\delta^{18} \mathrm{O}$ raw data from the Fiescherhorn ice cores (FH2002, black, FH1989, blue), together with the monthly temperature at the Jungfraujoch station (grey). Right panel: $\delta^{18} \mathrm{O}$ raw data from the Grenzgletscher ice core (black), together with the monthly temperature at the Grand Saint Bernard (grey).

Grenzgletscher (Eichler et al., 2000). The analytical uncertainties were $<0.05 \%$ for the Fiescherhorn and $<0.1 \%$ for the Grenzgletscher. More detailed description of the analytical procedures is given in Schwikowski et al. (1999) and Jenk (2006) for the Fiescherhorn cores and in Eichler et al. $(2000,2001)$ for the Grenzgletscher core. In the upper part discussed here (see also Sect. 2.1.3), the Fiescherhorn record contains $\sim 15-25$ data points per year and Grenzgletscher $\sim 20-90$ points per year. Assuming diffusion lengths of 7 $8 \mathrm{~cm}$ typical for firn conditions, smoothing of the isotope signal due to diffusion (Johnsen, 1977) is negligible for the investigated cores due to the high accumulation rates. Annual $\delta^{18} \mathrm{O}$ was obtained according to the dating procedure (see Sect. 2.1.1), averaging all the values belonging to the same year. To derive subannual values, the year (defined from minimum to minimum) was split into 12 evenly spaced sections after linear interpolation of the raw data and the four seasonal winter to autumn $\delta^{18} \mathrm{O}$ averages were calculated according to the convention (DJF, MAM, JJA, SON). This procedure assumes that the signal is uniformly deposited throughout the year, which might not be the case if seasonality or intraseasonal precipitation variability is present. In the Fiescherhorn ice core some melt features were observed, with low to moderate relocation of ions towards lower depths (Jenk, 2006). The Grenzgletscher concentration records were disturbed in the period 1985-1989 for certain major ions, due to the inflow of meltwater (Eichler et al., 2001). In contrast, the $\delta^{18} \mathrm{O}$ was not significantly affected by melting as shown in Schotterer et al. (1997) and Schwikowski et al. (1999) for Fiescherhorn and in Eichler et al. (2001) for Grenzgletscher.

\subsubsection{Ice core accumulation reconstruction}

The annual layer thickness $\lambda_{E}$ was obtained from the depth differences between the age markers of subsequent years. In order to correct for the changing density in the firn, results in metres total depth were normalized to metres water equivalent (mw.e.) by multiplying the depth of the sample with the respective density which was derived from measurements of the ice core segments (length typically between 30 and $70 \mathrm{~cm}$ ).

In order to reconstruct the net accumulation it is necessary to account for the ice thinning with depth (Cuffey and Paterson, 2010). We followed the approach given by Henderson et al. (2006) using

$\lambda_{\mathrm{R}}=\left(\lambda_{E} / \lambda_{\mathrm{M}}\right) \lambda_{0}$

where $\lambda_{R}$ is the reconstructed net accumulation, $\lambda_{E}$ the annual thickness, $\lambda_{\mathrm{M}}$ the annual thickness estimated from an ice flow model, and $\lambda_{0}$ the estimated surface accumulation rate. Here the correction factor $\lambda_{\mathrm{M}}$ was determined with the ice flow model proposed by Nye (1963), which assumes a constant thinning with depth. This assumption is generally only valid for the upper two-thirds of the glacier thickness of vast ice sheets (Hammer et al., 1978), but could still be applied in the case of Fiescherhorn and Grenzgletscher ice cores, because we deal with the uppermost $\sim 60$ and $\sim 70 \mathrm{~m}$ w.e. of a total of 124 and 170 (estimated) m w.e., respectively.

This model was previously used in two studies involving Fiescherhorn and Grenzgletscher. For Fiescherhorn it was compared to a more sophisticated accumulation reconstruction derived from the measurement of the vertical velocity of 
the ice (Schwerzmann et al., 2006). Here, we do not apply the latter reconstruction, because the dating of the Fiescherhorn ice core was revised and is based now on an extended data set after analyses of the stable isotopes and concentrations of major ions were completed. For Grenzgletscher the Nye model was applied as an additional and independent dating technique (Eichler et al., 2000).

In order to obtain $\lambda_{\mathrm{M}}$ we first used the reverse Nye function to fit the data (Dansgaard and Johnsen, 1969), using

$t=t_{0}-\frac{H}{\lambda_{0}} \ln \left(\frac{H-z}{H}\right)$,

where $t$ is the year, $t_{0}$ the drilling date (2002.92 for Fiescherhorn, 1994.67 for Grenzgletscher), $H$ the glacier thickness (124 m w.e. for Fiescherhorn, 170 m w.e. for Grenzgletscher), $z$ the height above the bed in mw.e., and $\lambda_{0}$ the surface accumulation rate in $\mathrm{m}$ w.e. year ${ }^{-1}$, estimated by averaging the upper layer thicknesses for which thinning can be neglected ( $1.7 \mathrm{~m}$ w.e. year ${ }^{-1}$ for Fiescherhorn, by averaging the layers from 1990 to 2002 , Jenk, 2006; $2.7 \mathrm{~m} \mathrm{w}$.e. year $^{-1}$ for Grenzgletscher, Eichler et al., 2000). The fit is characterized by a reduced $\chi^{2}=0.93$ over the upper $\sim 70 \mathrm{~m}$ w.e. in Fiescherhorn, corresponding to the period 1950-2002, and a reduced $\chi^{2}=0.67$ for Grenzgletscher over the period 19381994. We also obtained a reconstructed accumulation for FH1989, with $\lambda_{0}=1.4 \mathrm{~m}$ w.e. year $^{-1}$, after Schwikowski et al. (1999), and $t_{0}=1989$, giving a reduced $\chi^{2}=0.39$ for the whole period 1946-1989. The difference between the two Fiescherhorn cores' $\lambda_{0}$ arises only due to the different period used for the estimation of the surface accumulation rate. We retrieved the modelled depth corresponding to the calendar year and formed, in analogy with $\lambda_{E}$, the modelled layer thickness $\lambda_{M}$.

\subsection{Weather data}

For the analysis of the temporal and spatial variability of the ice core proxies we used data collected at weather stations near the glaciers as well as gridded data. The correlation analyses were done by calculating the Pearson coefficient and the relation between $\delta^{18} \mathrm{O}$ and temperature was evaluated by regression analysis. The presence of possible outliers was investigated by evaluating the jackknife residuals. The temperature and precipitation data are from the weather stations operated by the Federal Office of Climatology and Meteorology in Switzerland (Meteoswiss). When available, homogenized data were used. For Fiescherhorn this is the homogenized temperature from the high-Alpine weather station at the Jungfraujoch, only $6 \mathrm{~km}$ west of the site $\left(46^{\circ} 33^{\prime} \mathrm{N}\right.$, $7^{\circ} 59^{\prime} \mathrm{E}, 3580 \mathrm{~m}$ a.s.l). Since precipitation is not measured at Jungfraujoch, data from nearby stations were considered instead (Sect. 3.2.1). For Grenzgletscher we utilized homogenized temperature and precipitation data from the highAlpine station of the Grand Saint Bernard $\left(45^{\circ} 52^{\prime} \mathrm{N}, 7^{\circ} 10^{\prime} \mathrm{E}\right.$, $2472 \mathrm{~m}$ a.s.l.), located $50 \mathrm{~km}$ west of the site, as explained in Sects. 3.1 and 3.2, and from Locarno $\left(46^{\circ} 10^{\prime} \mathrm{N}, 8^{\circ} 47^{\prime} \mathrm{E}\right.$, $367 \mathrm{~m}$ a.s.l.) in Ticino (southern Switzerland). The location of the weather stations is shown in Fig. 1. For the spatial correlation analysis gridded data of temperature and precipitation were used. We selected the surface temperature and $700 \mathrm{hPa}$ temperature from the Twentieth Century Reanalysis data set (Compo et al., 2011), ERA40 (Uppala et al., 2005), and NCEP-NCAR R1 (Kalnay et al., 1996), respectively. Out of these the Twentieth Century Reanalysis has the highest spatial resolution $\left(2^{\circ} \times 2^{\circ}\right)$. We excluded other higherresolution reanalysis products like ERA-Interim, MERRA or CFSR because their data sets only start in 1979 . We focused on the region from $40^{\circ}$ to $60^{\circ} \mathrm{N}$ and from $15^{\circ} \mathrm{W}$ to $25^{\circ} \mathrm{E}$. For precipitation, because of its sporadic nature in space and time, we used higher-resolution data provided by Meteoswiss (nominally $2.2 \mathrm{~km}$, actually $15-20 \mathrm{~km}$, corresponding to the mean inter-station distance). This monthly, gridded data set covers the area of Switzerland, starts in 1961, and is based on precipitation data collected within the rain-gauge network of Meteoswiss (Frei and Schär, 1998). Due to the scarcity of weather stations at high altitude, the uncertainty of precipitation data over the Alps is estimated to be $25-30 \%$ (Meteoswiss, 2013). The resulting period of overlap among the different data sets (20th century Reanalysis, Meteoswiss gridded data) and the ice core data is 1961-1993 for Grenzgletscher (with a gap between 1968 and 1970, as explained in Sect. 2.1.1) and 1961-2001 for Fiescherhorn.

We additionally used the $\delta^{18} \mathrm{O}$ measured in meteoric water at four GNIP stations: Bern (541 ma.s.l.), Meiringen (632 m a.s.1.), Guttannen (1055 m a.s.l.) and Grimsel Hospiz (1950 m a.s.l.). For their location see Fig. 1. The collection of monthly meteoric water at these stations started in January 1970 for Bern, and August 1970 for the others, and $\delta^{18} \mathrm{O}$ measurements were performed by the Climate and Environmental Physics Department of the Physics Institute of the University Bern, Switzerland (IAEA/WMO, 2013). Since July 1992, the data collection at the GNIP stations in Switzerland has been carried out by the Swiss Geological Survey at the Federal Office of the Environment (FOEN), through the NISOT network (Swiss National Network for Isotopes in the Water Cycle; Schürch et al., 2003).

For the comparison between the two ice cores, the resulting common period is 1961-1993 (with a gap in 1968-1970) and for the analysis with the GNIP data the common period is 1971-1993 (1980 excluded, as explained later). 
Table 1. Mean values of $\delta^{18} \mathrm{O}$ from the GNIP stations as well as from the ice cores over the common period 1971-1993, together with the slope of the long-term $\delta^{18} \mathrm{O} /$ temperature calibration and the $R^{2}$ for the seasonal and the annual scale. For the seasonal scale, values were calculated for the common period 1972-1993 (1971 and 1980 excluded because of gaps in the data). For the annual scale, the year 1980 was excluded. The temperatures used to calibrate the GNIP $\delta^{18} \mathrm{O}$ were measured at the respective stations, whereas for the ice cores the Jungfraujoch temperature was used for the Fiescherhorn and the Grand Saint Bernard for the Grenzgletscher. The suffix "UNW" stands for the unweighted average and "PW" for precipitation-weighted average.

\begin{tabular}{|c|c|c|c|c|c|c|c|}
\hline & \multirow[b]{2}{*}{$\begin{array}{r}\text { Mean } \\
(\% o)\end{array}$} & \multicolumn{2}{|c|}{ Seasonal scale } & \multicolumn{2}{|c|}{$\begin{array}{l}\text { Seasonal scale } \\
\text { (anomalies) }\end{array}$} & \multicolumn{2}{|c|}{ Annual scale } \\
\hline & & $\begin{array}{c}\text { Slope } \\
\left(\% 0^{\circ} \mathrm{C}^{-1}\right)\end{array}$ & $R^{2}$ & $\begin{array}{r}\text { Slope } \\
\left(\% 0^{\circ} \mathrm{C}^{-1}\right)\end{array}$ & $R^{2}$ & $\begin{array}{c}\text { Slope } \\
\left(\% 0^{\circ} \mathrm{C}^{-1}\right)\end{array}$ & $R^{2}$ \\
\hline Bern & -9.89 & $0.32 \pm 0.02$ & 0.69 & $0.45 \pm 0.14$ & 0.11 & $0.57 \pm 0.32$ & 0.14 \\
\hline Meiringen & -11.35 & $0.42 \pm 0.03$ & 0.73 & $0.67 \pm 0.16$ & 0.17 & $0.88 \pm 0.41$ & 0.19 \\
\hline Guttannen & -12.54 & $0.46 \pm 0.03$ & 0.71 & $0.49 \pm 0.15$ & 0.12 & $0.72 \pm 0.35$ & 0.18 \\
\hline Grimsel Hospiz & -14.23 & $0.43 \pm 0.03$ & 0.70 & $0.57 \pm 0.11$ & 0.23 & $0.68 \pm 0.20$ & 0.36 \\
\hline FH2002 & -16.53 & $0.47 \pm 0.05$ & 0.55 & $-0.22 \pm 0.16$ & 0.02 & $0.44 \pm 0.22$ & 0.17 \\
\hline GG (with $T_{\mathrm{UNW}}$ ) & -17.34 & $0.53 \pm 0.05$ & 0.56 & $0.28 \pm 0.21$ & 0.02 & $0.27 \pm 0.53$ & 0.01 \\
\hline GG (with $T_{\mathrm{PW}}$ ) & -17.34 & $0.55 \pm 0.05$ & 0.58 & $0.47 \pm 0.20$ & 0.07 & $0.77 \pm 0.32$ & 0.22 \\
\hline
\end{tabular}

\section{Results and discussion}

\section{1 $\delta^{18} \mathrm{O}$ and temperature}

\subsubsection{Seasonal scale}

Ice core raw $\delta^{18} \mathrm{O}$ data from the Fiescherhorn and the Grenzgletscher sites span the characteristic summer-to-winter values between -10 and $-25 \%$ o (Fig. 3) expected for the respective altitudes (Siegenthaler and Oeschger, 1980; Sigl, 2009). Very good agreement is found between the two Fiescherhorn series $(r=0.79, p<0.001)$, indicating that the mean conditions are homogeneously recorded at the glacier. We compared the seasonal $\delta^{18} \mathrm{O}$ averages of the Fiescherhorn and Grenzgletscher ice core with the temperature data from the weather stations Jungfraujoch and Grand Saint Bernard, respectively (see also Sect. 2.2). Ice core $\delta^{18} \mathrm{O}$ records and temperature data agree well for most of the years, clearly showing seasonality in the isotopic records. The seasonal cycle is remarkably well captured in the ice cores $(r=0.70, p<0.001$ for Fiescherhorn, period 1961-2001, $r=0.69, p<0.001$ for Grenzgletscher, period 1961-1993). Similar correlation was found for Grenzgletscher when using the precipitation-weighted seasonal temperature at the Grand Saint Bernard ( $r=0.71, p<0.001$, see also Sect. 3.1.2). In the case of Fiescherhorn, precipitation-weighting was not possible because no precipitation data are available for the Jungfraujoch high-altitude station which might be most representative for the Fiescherhorn. Also no clear relation between Fiescherhorn accumulation and precipitation at nearby weather stations was observed (see Sects. 3.1.2 and 3.2.1). The results for Grenzgletscher are in good agreement with a previous study by Eichler et al. (2001), using a similar approach based on monthly data from Grenzgletscher and Grand Saint Bernard for the period 1980-1994 $(r=0.7)$.
In order to investigate the suitability of the ice core $\delta^{18} \mathrm{O}$ signal as a temperature proxy we compared the established $\delta^{18} \mathrm{O} / T$ relationship with results from the nearest GNIP stations. To mimic the seasonal distribution of precipitation affecting the $\delta^{18} \mathrm{O}$ at high-Alpine sites, the seasonal precipitation-weighted mean from the monthly $\delta^{18} \mathrm{O}$ GNIP data was used, following the suggestion by Siegenthaler and Oeschger (1980). No adjustment to the temperature data accounting for the altitude difference between station and ice core sites was applied (moist adiabatic lapse rate of $\sim-0.6^{\circ} \mathrm{C} / 100 \mathrm{~m}$ ), since only the slope of the $\delta^{18} \mathrm{O} / T$ regression line is of interest in this context. The overlapping period with available station and ice core data is 1971-1993. Two years (1971 and 1980) were excluded because of missing values in winter 1971 in the Grenzgletscher record and in summer 1980 in the Guttannen station record. The results are summarized in Table 1. For the four GNIP stations we obtained slopes ranging between $0.32 \pm 0.02 \% 0^{\circ} \mathrm{C}^{-1}$ (Bern) and $0.46 \pm 0.03 \% 0^{\circ} \mathrm{C}^{-1}$ (Guttannen), comparable to the values found by Siegenthaler and Oeschger (1980) using monthly data over the period 1971-1978 $\left(0.35,0.53,0.55\right.$, and $0.44 \% 0^{\circ} \mathrm{C}^{-1}$ for Bern, Meiringen, Guttannen, and Grimsel Hospiz, respectively). For the Fiescherhorn/Jungfraujoch $\delta^{18} \mathrm{O} / T$ relation the slope is $0.47 \pm 0.05 \% 0^{\circ} \mathrm{C}^{-1} \quad\left(R^{2}=0.55\right)$. Similar values were found for the $\delta^{18} \mathrm{O} / T$ relation between Grenzgletscher $\delta^{18} \mathrm{O}$ and Grand Saint Bernard temperature $\left(0.55 \pm 0.05 \% 0^{\circ} \mathrm{C}^{-1}\right.$ and $0.53 \pm 0.05 \% 0^{\circ} \mathrm{C}^{-1}$ with $R^{2}=0.58$ and 0.56 for the precipitation-weighted and unweighted temperature, respectively; see also Sect. 3.1.2). This does not change significantly when the entire period (1961-2001 for FH2002 and 1961-1993, 1968-1970 excluded for Grenzgletscher) is considered: $0.46 \pm 0.04 \% 0^{\circ} \mathrm{C}^{-1}$ for Fiescherhorn, $0.48 \pm 0.05 \%{ }^{\circ} \mathrm{C}^{-1}$ and $0.50 \pm 0.05 \%{ }^{\circ} \mathrm{C}^{-1}$ for the 


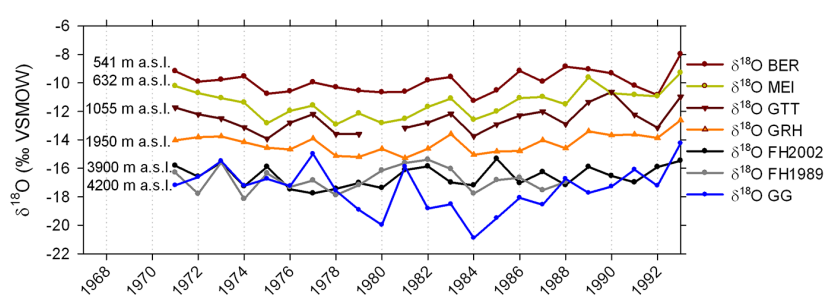

Figure 4. Annual precipitation-weighted $\delta^{18} \mathrm{O}$ from the GNIP stations together with the ice core data. The sites are indicated as follows: Bern (BER), Meiringen (MEI), Guttannen (GTT), Grimsel Hospiz (GRH), Fiescherhorn (FH), Grenzgletscher (GG). The gaps in the GNIP data are due to missing data points for the corresponding years. The altitude of each site is indicated on the left.

Grenzgletscher unweighted and precipitation-weighted temperature, respectively. In general the fraction of $\delta^{18} \mathrm{O}$ variance explained by temperature changes is $\sim 60 \%$ compared to $\sim 70 \%$ in the GNIP data. In order to check whether the obtained relationships are mainly due to the seasonal cycle, seasonal anomalies of both $\delta^{18} \mathrm{O}$ and temperature were analysed in addition (Liu et al., 2010). The seasonal anomalies are the remaining variation after subtracting the seasonal cycle from the data. The typical seasonal cycle was derived by averaging the isotopic or temperature values, respectively, for winter (DJF), spring (MAM), summer (JJA) and autumn (SON) of the years 1972 to 1993 (Table 1). After removing the seasonal cycle the values of the fraction of $\delta^{18} \mathrm{O}$ variance explained by temperature changes given above decrease significantly for all sites and in this case range between $0-10 \%$ for the ice core data and $10-25 \%$ for the GNIP station data. This indicates that the major part of the correlation is determined by the seasonal cycle if not removed. The slopes, however, do not change significantly between the seasonal and deseasonalized case but they are smaller compared to what would be expected from Rayleigh distillation processes. This suggests that other factors such as precipitation intermittency and changes in the moisture source play a role. For the lower elevation stations receiving liquid precipitation, belowcloud processes may further affect the isotopic composition of water whereas for the ice core data, effects due to postdepositional processes need to be assumed as indicated by the very low coefficients.

\subsubsection{Annual scale}

For paleoclimatic reconstructions the $\delta^{18} \mathrm{O} / T$ relation on an annual scale becomes fundamental because with depth, the proxy resolution decreases to a few points per year due to glacier flow induced layer thinning and seasonal resolution cannot be obtained anymore. The annual averages of $\delta^{18} \mathrm{O}$ are shown in Fig. 4 to highlight the altitude effect. For the common time period, the mean $\delta^{18} \mathrm{O}$ ice core values decrease with increasing altitude from $-16.53 \%$ at Fiescherhorn (3900 ma.s.l.) to

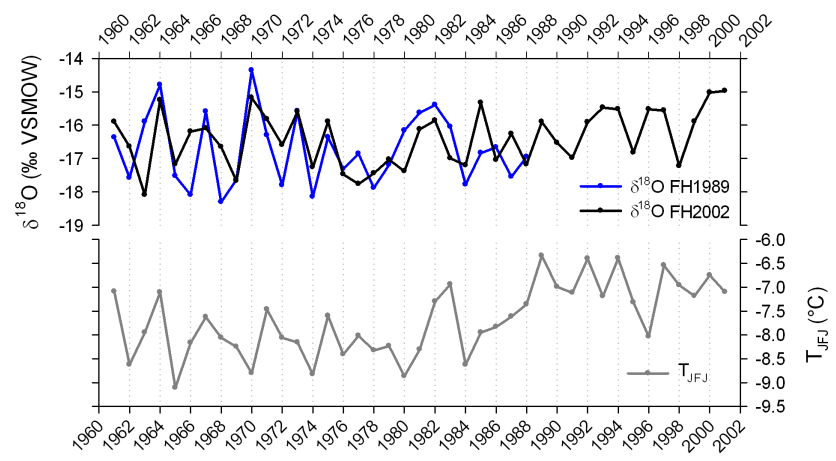

Figure 5. Annual $\delta^{18} \mathrm{O}$ from FH2002 ice core (black), FH1989 (blue), together with the annual mean temperature at the Jungfraujoch weather station (grey).

$-17.34 \%$ at Grenzgletscher (4200 ma.s.1.). This result is consistent with the altitude effect resulting in a lapse rate of $\mathrm{d} \delta^{18} \mathrm{O} / \mathrm{d} z=-0.2 \% o / 100 \mathrm{~m}$ reported by Siegenthaler and Oeschger (1980) and Schürch et al. (2003). A similar value of $\mathrm{d} \delta^{18} \mathrm{O} / \mathrm{d} z=-0.17 \pm 0.02 \% / 100 \mathrm{~m}\left(R^{2}=0.94\right)$ was found in this study for an extended elevation range combining data of the two ice core sites and the four GNIP stations.

For the correlation of the two Fiescherhorn $\delta^{18} \mathrm{O}$ series the resulting high-correlation coefficient (Fig. 5, $r=0.52$, $p<0.01$, period 1961-1988) demonstrates that on an annual scale the two ice cores do representatively capture the conditions at the glacier. In the following we focus on the FH2002 core which also covers the more recent time period.

The recent warming (Appenzeller et al., 2008) is particularly pronounced in the Jungfraujoch temperature with a stepwise increase after the year $\sim 1984$. At the Fiescherhorn a more gradual $\delta^{18} \mathrm{O}$ increase is observed after 1984, more similar to the trends at the Grenzgletscher, the four GNIP stations and the Grand Saint Bernard temperature (Figs. 4, 5 and 6).

The annual Fiescherhorn $\delta^{18} \mathrm{O}$ correlates significantly with the Jungfraujoch annual temperature $(r=0.44$, $p<0.01$, period 1961-2001). The resulting slope is $(0.50 \pm 0.16) \% 0^{\circ} \mathrm{C}^{-1}$ which is consistent with the result based on the seasonal values. The slope is substantially different from what was found by Schotterer et al. (1997) for the annual values of FH1989 over the period 1969-1989 $\left(1.1 \% 0^{\circ} \mathrm{C}^{-1}, R^{2}=0.74\right)$. In order to get a reasonable correlation, Schotterer et al. (1997) had to exclude four years with strongly anomalous data $(1971,1972,1981,1988)$. In the case of FH2002, even when excluding two suspected outliers determined with the jackknife residuals (1963 and 1970), despite a higher Pearson coefficient $(r=0.54, p<0.001)$, the slope does not change significantly $\left(0.58 \pm 0.15 \% 0^{\circ} \mathrm{C}\right)$. In the case of Grenzgletscher the annual temperature and the $\delta^{18} \mathrm{O}$ do not show any significant correlation within the dating uncertainty $(-1,0,+1$ year), neither with the Grand Saint Bernard or the Locarno station data nor with 
the gridded data (not shown). Because in first approximation the $\delta^{18} \mathrm{O}$ is a proxy for the in-cloud temperature only when precipitation occurs, one neglects a potential effect due to the seasonal distribution of precipitation, when comparing the $\delta^{18} \mathrm{O}$ on the glacier with the mean annual temperature. We assume that at the Grenzgletscher the non-uniform snow deposition throughout the year is more pronounced than at Fiescherhorn (see Sect. 3.2.1), as is generally the case in the southern Alps compared to the northern Alps (Frei and Schär, 1998; Eichler et al., 2004; Sodemann and Zubler, 2009). To account for the higher variability of precipitation at the Grenzgletscher we calculated the precipitation-weighted temperature according to

$T_{\text {ann }}=\frac{\sum_{i=1}^{12} P_{i} T_{i}}{P_{\text {ann }}}$,

where $T_{\text {ann }}$ is the annual precipitation weighted temperature, $P_{i}$ the monthly amount of precipitation used to weight the monthly temperature $T_{i}$, and $P_{\text {ann }}$ the annual amount of precipitation. Since it is not possible to get subannual information from the reconstructed accumulation (only annual layer thickness is retrieved), we mimicked the monthly precipitation at the Grenzgletscher using the data from the highaltitude station Grand Saint Bernard instead. This is reasonable based on the good agreement between the precipitation at that station and accumulation at the site (see Sect. 3.2). The unweighted and precipitation-weighted annual temperatures are shown in Fig. 6. The precipitation-weighted annual temperatures are lower than the unweighted temperatures (mean of $-2.2{ }^{\circ} \mathrm{C}$ compared to $-1.1^{\circ} \mathrm{C}$ ), because of the observed higher precipitation in winter compared to summer at the Grand Saint Bernard (607, 611, 419, $568 \mathrm{~mm}$ in winter, spring, summer, and autumn, respectively, over 1961-1993, data provided by Meteoswiss). As expected, the correlation significantly increases $(r=0.45, p<0.05)$ with respect to the unweighted temperature $(r=0.16, p=0.20)$. We obtained a similar result when using the unweighted and precipitation-weighted data from the lower altitude station of Locarno, with the correlation coefficients increasing from $r=0.12(p=0.27)$ to $r=0.21 \quad(p=0.14)$. Due to the better agreement with the Grand Saint Bernard station, the corresponding slope $\delta^{18} \mathrm{O} / T$ for Grenzgletscher was determined using high-Alpine temperature data from this site and is $0.68 \pm 0.26 \%{ }^{\circ} \mathrm{C}^{-1}$ (precipitation-weighted temperature) compared to $0.39 \pm 0.47 \% 0^{\circ} \mathrm{C}^{-1}$ (unweighted temperature) for the time period 1961-1993. The obtained $\delta^{18} \mathrm{O} / T$ relationship based on the annual ice core data was compared with results from the near GNIP stations (Table 1) to infer differences between seasonal and annual information. We considered again the common period 1971-1993 (Fig. 7). Suspected outliers were evaluated with the jackknife residuals, but the exclusion of these points did not significantly change the slopes. In all cases except for the GG unweighted data,

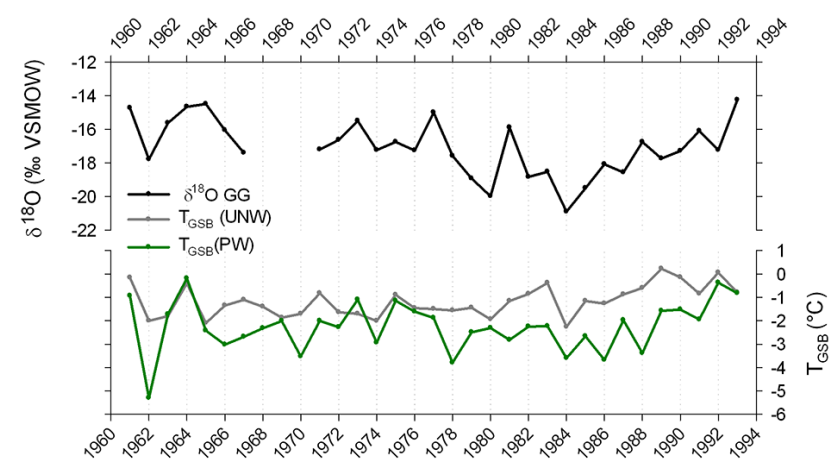

Figure 6. Annual $\delta^{18} \mathrm{O}$ from the Grenzgletscher (black), together with the annual mean temperature at the Grand Saint Bernard station. In grey the unweighted (UNW) temperature, in green the precipitation-weighted (PW) temperature, obtained as described in Sect. 3.1

i.e. for both the ice core and station data, the general capability to reproduce the temperature is significant (at least $p<0.10$ for all sites). The percentage of $\delta^{18} \mathrm{O}$ variance explained by temperature changes is about $20 \%$ on an annual scale which is comparable to the value obtained for the deseasonalized data and is explained by the reduced data set and the stronger bias of the non-uniformity of precipitation on the annual compared to the seasonal scale as well as by changes in the moisture sources throughout the year and post-depositional processes. As described above, no correlation exists with the annual mean temperature for the Grenzgletscher, indicating that precipitation intermittency and variability plays a fundamental role there (Persson et al., 2011).

\subsubsection{Spatial correlations}

We finally investigated the capability of the ice core $\delta^{18} \mathrm{O}$ to capture the regional temperature, performing a spatial correlation analysis with gridded instrumental data. The analysis was done with the KNMI Climate Explorer tool available on http://climexp.knmi.nl (Trouet and Van Oldenborgh, 2013). Figure 8 a shows the spatial correlation between Fiescherhorn annual $\delta^{18} \mathrm{O}$ and the Twentieth Century Reanalysis temperature at $700 \mathrm{hPa}$, which was considered to be most representative for the high elevation of the studied glacier sites. We observed significant correlation with temperature in central and southern Europe at $700 \mathrm{hPa}$ and at the surface level (not shown). Similar patterns were seen with the ERA40 and NCEP-NCAR R1 reanalyses (not shown), indicating no significant differences between the reanalysis data sets. We compared this result with the spatial correlation pattern of the Jungfraujoch temperature with the gridded data. Figure $8 \mathrm{~b}$ shows the pattern centred over Switzerland with coefficients higher than 0.7 for most of Europe. Comparing the two patterns, it is clear that the $\delta^{18} \mathrm{O}$ captures less variability and is representative for a smaller region only, which is not 

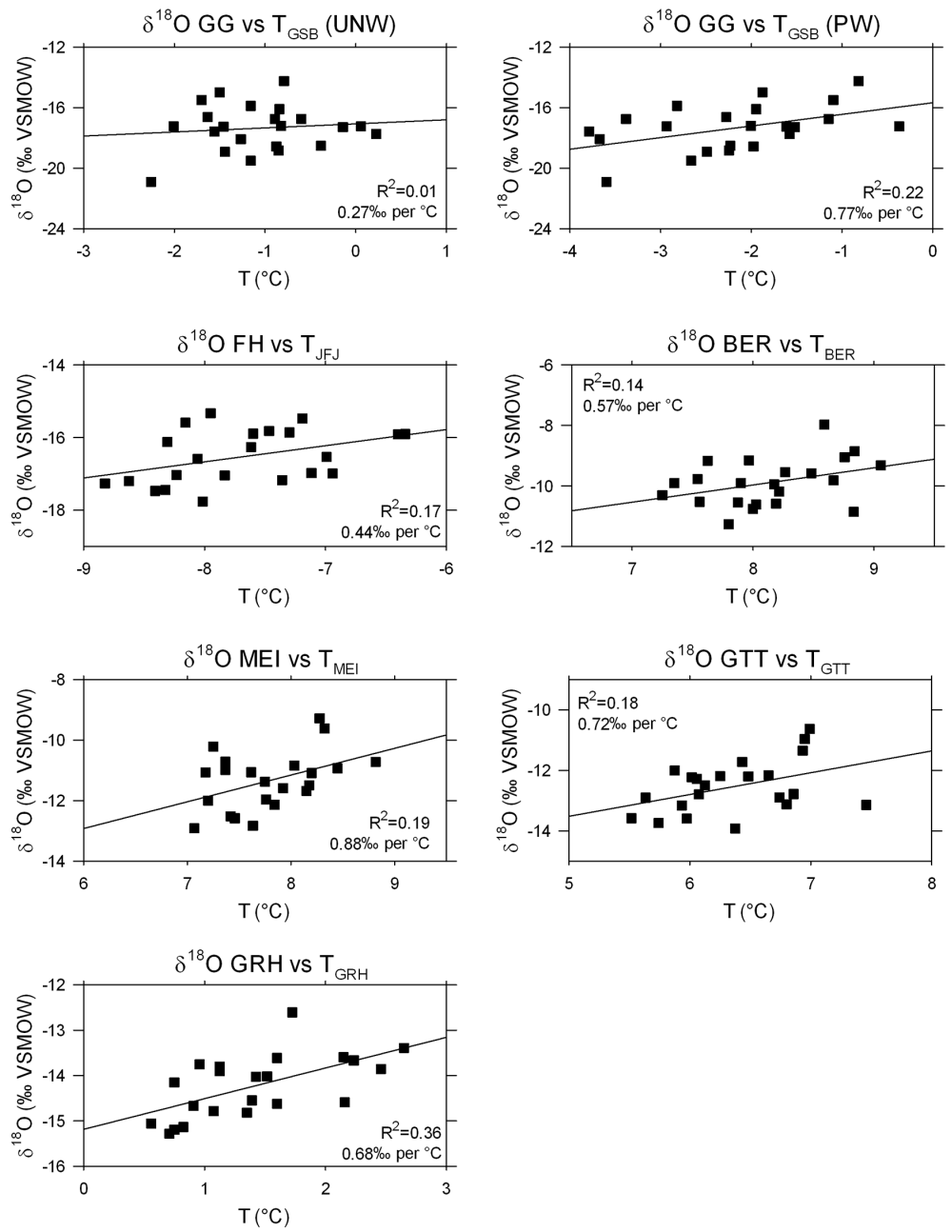

Figure 7. Scatter plots of annual temperature and $\delta^{18} \mathrm{O}$ data over the common period 1971-1993. The sites are denoted as follows: Grenzgletscher (GG), Grand Saint Bernard (GSB), Fiescherhorn (FH), Jungfraujoch (JFJ), Bern (BER), Meiringen (MEI), Guttannen (GTT), Grimsel Hospiz (GRH). "UNW" stands for the unweighted temperature and "PW" for precipitation-weighted temperature.

unexpected based on the fact that the temperature explains only $20 \%$ of the isotopic variance.

For Grenzgletscher we found significant correlations at both $700 \mathrm{hPa}$ and surface level (not shown) with the Twentieth Century Reanalysis precipitation-weighted temperature (each grid point was weighted with the monthly Grand Saint Bernard precipitation). This is in agreement with the previous results where the ice core data compared to the Grand Saint Bernard and Locarno station data showed a correlation with the precipitation-weighted temperatures. A similar pattern slightly shifted westwards and elongated towards a west-east direction was observed (Fig. 8c, for the $700 \mathrm{hPa}$ temperature), compared to the imprint of the regional temperature on the southern Alpine station (Fig. 8d). The latter is very similar to the pattern obtained in Fig. $8 \mathrm{~b}$ for the northern Alpine station.

The results obtained for the station data indicate that temperature variations on an annual scale are rather homogeneous over the whole of Europe. This suggests that ice core based temperature reconstructions (precipitationweighted in the case of Grenzgletscher) are in principle valid on a regional scale and could be interpreted even as a central European temperature. The result further underlines that the two glaciers, distant apart by only $60 \mathrm{~km}$, behave significantly differently in the way the isotopic signal is recorded. At Fiescherhorn the annual $\delta^{18} \mathrm{O}$ in precipitation reasonably represents the mean annual temperature, implying a nearly homogeneous preservation of precipitation throughout the year. At Grenzgletscher, because of the high variability in precipitation throughout the seasons, the average temperature during precipitation deduced from the ice core $\delta^{18} \mathrm{O}$ differs significantly from the annual mean temperature. 


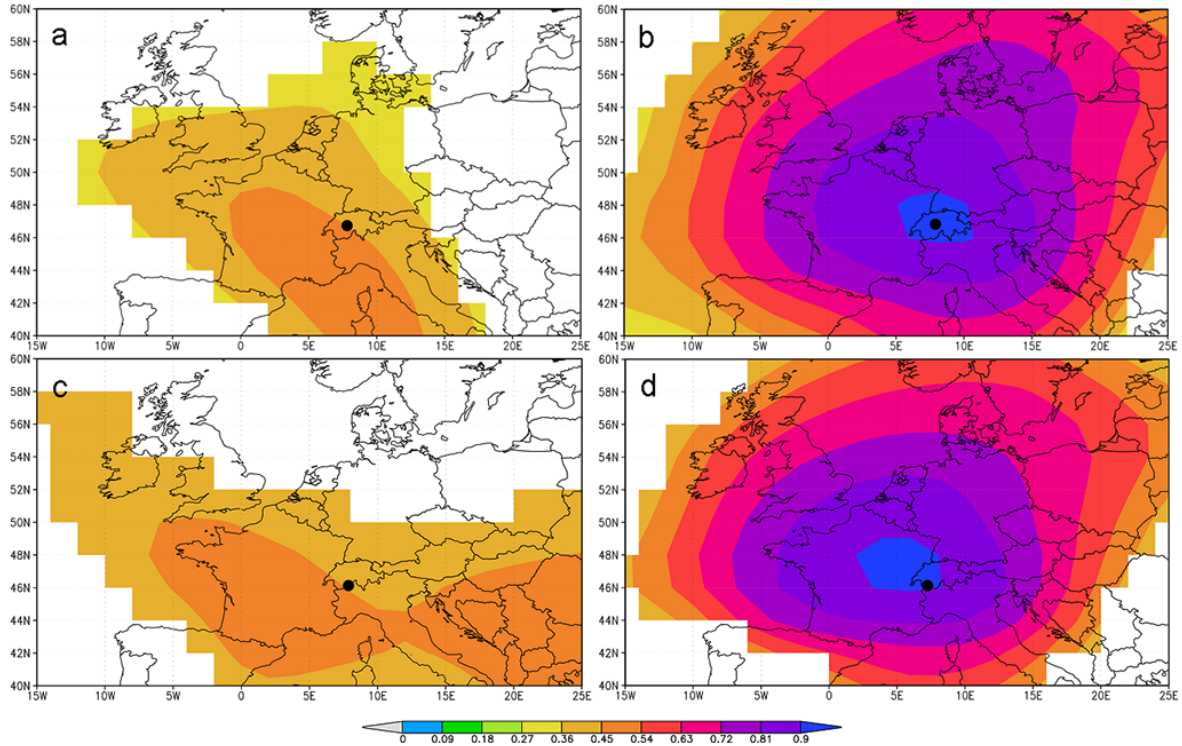

Figure 8. Spatial correlation maps of annual $\delta^{18} \mathrm{O}$ and temperature records with the Twentieth Century Reanalysis $700 \mathrm{hPa}$ temperature, for northern Alpine (upper panels, period 1961-2001) and southern Alpine sites (lower panels, period 1961-1993, 1968-1970 excluded). Correlation with (a) Fiescherhorn $\delta^{18} \mathrm{O}$, (b) Jungfraujoch temperature, (c) Grenzgletscher $\delta^{18} \mathrm{O}$ (using the 20th century Reanalysis $700 \mathrm{hPa}$ precipitation-weighted temperature, Grand Saint Bernard precipitation utilized to weight the temperature), (d) Grand Saint Bernard temperature. Black dots indicate the location of the sites. Areas with correlation coefficients statistically significant at the $5 \%$ level are shaded.

\subsection{Net accumulation and precipitation}

\subsubsection{Comparison with the station data}

The time series of the reconstructed annual net accumulation at Fiescherhorn and Grenzgletscher together with the annual precipitation from nearby weather stations are shown in Fig. 9a-b and $\mathrm{c}-\mathrm{d}$, respectively. For the northern and southern sites we selected a low-altitude (Interlaken, $577 \mathrm{~m}$ a.s.l. and Locarno, $367 \mathrm{~m}$ a.s.l., respectively) and a high-altitude station (Grimsel Hospiz, and Grand Saint Bernard, respectively). For their geographic locations see Fig. 1.

The two Fiescherhorn reconstructions are well correlated with each other $(r=0.66, p<0.001)$, indicating similar preservation of the precipitation at the two sites, $100 \mathrm{~m}$ apart. With focus on the common period 1961-1993, Grenzgletscher has a higher mean accumulation and interannual variability $(2.7 \mathrm{mw}$.e., $1 \sigma=0.8 \mathrm{~m}$ w.e. $\sim 30 \%$ ) compared to the Fiescherhorn record ( $1.7 \mathrm{~m}$ w.e., $1 \sigma=0.4 \mathrm{~m}$ w.e. $\sim 23 \%$ ) (see Fig. 9). This is in agreement with higher precipitation for stations in the southern Alps. The two stations in the northern Alps reveal a mean precipitation and interannual variability of $1183 \mathrm{~mm}$ and $12 \%$ (Interlaken), $1881 \mathrm{~mm}$ and $18 \%$ (Grimsel Hospiz), and the southern stations $1858 \mathrm{~mm}$ and $19 \%$ (Locarno), $2214 \mathrm{~mm}$ and 14\% (Grand Saint Bernard). As shown in Fig. 9, precipitation increases with altitude at the southern sites including the Grenzgletscher. For the northern stations the increase is even more pronounced. However, Fiescherhorn accumulation is lower than precipitation at the Grimsel Hospiz. This could be explained by local phenomena, probably related to wind erosion at the exposed Fiescherhorn saddle. Post-depositional processes could also be responsible for the higher interannual variability at the glacier sites compared to the stations.

Comparing the precipitation records of the northern stations with the Fiescherhorn record (Fig. 9, Table 2), we found a significant correlation with most stations only in the earlier part (1961-1977) when allowing the ice core series to be shifted by -1 year, which is within the given dating uncertainty. The Fiescherhorn accumulation maximum around 1977 is not recorded in the northern station data, but pronounced at southern sites including the Grenzgletscher. This might indicate that the common precipitation features between the northern and the southern sites are better captured at the Fiescherhorn than at the respective low-altitude stations. No correspondence with precipitation in the most recent period (1978-2001) was found, probably indicating a general change in the pattern of received precipitation or the local influence of post-depositional processes such as wind erosion, but this is not understood at this point. The earlier part dominates the overall correlation over the whole period 1961-2001, as shown in Table 2.

For the Grenzgletscher we found a significant correlation between the reconstructed ice core accumulation, the Grand Saint Bernard $(r=0.58, p<0.001)$ and the Locarno precipitation $(r=0.59, p<0.001)$, indicating that the sites located 
Table 2. Mean annual precipitation over the period 1961-2001 for the stations near the Fiescherhorn glacier, together with their interannual variability, expressed as $1 \sigma /$ mean value in percent (in parentheses). Asterisks indicate homogenized data. Pearson correlation coefficient of the precipitation with the annual net accumulation (offset $=-1$ year) at Fiescherhorn glacier. Values of correlation coefficients statistically significant at the $5 \%$ level are in bold.

\begin{tabular}{|c|c|c|c|c|c|c|}
\hline \multirow[t]{2}{*}{ Station } & \multicolumn{2}{|c|}{ Coordinates } & \multirow{2}{*}{$\begin{array}{l}\text { Altitude } \\
\text { (m a.s.l.) }\end{array}$} & \multirow{2}{*}{$\begin{array}{l}\text { Mean annual } \\
\text { precipitation } \\
(1961-2001) \\
(\mathrm{mm})\end{array}$} & \multirow{2}{*}{$\begin{array}{c}r \\
(1961-2001)\end{array}$} & \multirow{2}{*}{$\begin{array}{c}r \\
\text { (1961-1977) }\end{array}$} \\
\hline & Latitude & Longitude & & & & \\
\hline 1. Engelberg* & $46^{\circ} 49^{\prime} \mathrm{N}$ & $8^{\circ} 25^{\prime} \mathrm{E}$ & 1035 & $1533(11 \%)$ & 0.25 & 0.54 \\
\hline 2. Grimsel Hospiz* & $46^{\circ} 34^{\prime} \mathrm{N}$ & $8^{\circ} 20^{\prime} \mathrm{E}$ & 1950 & $1908(17 \%)$ & 0.26 & 0.53 \\
\hline 3. Grindelwald & $46^{\circ} 38^{\prime} \mathrm{N}$ & $8^{\circ} 02^{\prime} \mathrm{E}$ & 1158 & $1398(14 \%)$ & 0.20 & 0.49 \\
\hline 4. Guttannen & $46^{\circ} 39^{\prime} \mathrm{N}$ & $8^{\circ} 17^{\prime} \mathrm{E}$ & 1055 & $1732(13 \%)$ & 0.32 & 0.66 \\
\hline 5. Interlaken & $46^{\circ} 40^{\prime} \mathrm{N}$ & $7^{\circ} 52^{\prime} \mathrm{E}$ & 577 & $1192(13 \%)$ & 0.41 & 0.51 \\
\hline 6. Kleine Scheidegg & $46^{\circ} 35^{\prime} \mathrm{N}$ & $7^{\circ} 58^{\prime} \mathrm{E}$ & 2061 & $1586(14 \%)$ & 0.13 & 0.42 \\
\hline 7. Lauterbrunnen & $46^{\circ} 36^{\prime} \mathrm{N}$ & $7^{\circ} 54^{\prime} \mathrm{E}$ & 818 & $1181(13 \%)$ & 0.28 & 0.56 \\
\hline 8. Leukerbad & $46^{\circ} 23^{\prime} \mathrm{N}$ & $7^{\circ} 38^{\prime} \mathrm{E}$ & 1390 & $1224(19 \%)$ & 0.40 & 0.55 \\
\hline 9. Meiringen & $46^{\circ} 44^{\prime} \mathrm{N}$ & $8^{\circ} 10^{\prime} \mathrm{E}$ & 632 & $1353(13 \%)$ & 0.37 & 0.60 \\
\hline 10. Mürren & $46^{\circ} 33^{\prime} \mathrm{N}$ & $7^{\circ} 53^{\prime} \mathrm{E}$ & 1638 & $1462(14 \%)$ & 0.33 & 0.43 \\
\hline
\end{tabular}

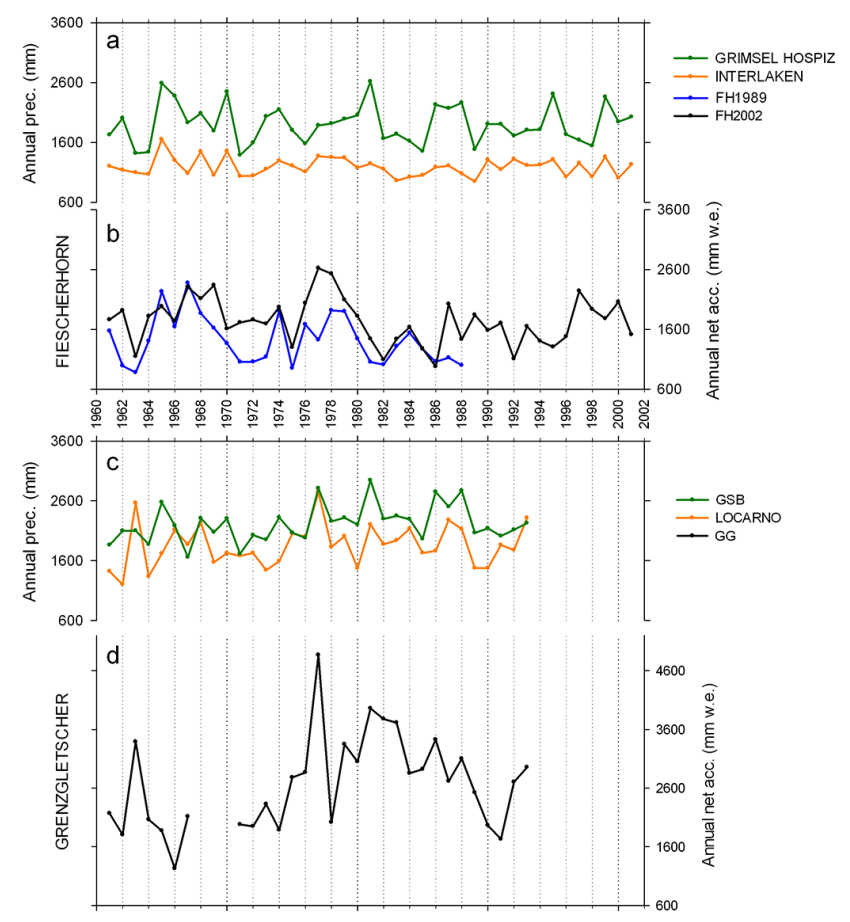

Figure 9. (a) Annual sum of precipitation from the high- and lowaltitude stations Grimsel Hospiz (1950 m a.s.l., green) and Interlaken (577 m a.s.1., orange). (b) Reconstructed annual accumulation at the Fiescherhorn glacier for FH2002 (black) and FH1989 (blue). (c) Annual sum of precipitation from the high- and lowaltitude stations Grand Saint Bernard (2472 m a.s.l., green) and Locarno (367 m a.s.1., orange). (d) Reconstructed annual accumulation at the Grenzgletscher (black). Note that the panels are shown on the same scale, to allow a direct comparison of the records. in the southern Alps are likely affected by the same precipitation regime (Fig. 9c-d).

In order to test how the precipitation and temperature proxies potentially affect each other we correlated the ice cores $\delta^{18} \mathrm{O}$ with the respective reconstructed accumulations. However, we did not find significant correlations between the Grenzgletscher and Fiescherhorn $\delta^{18} \mathrm{O}$ and the respective reconstructed accumulation.

\subsubsection{Spatial correlations}

In order to see whether the two glaciers record the different precipitation patterns expected due to the orographic barrier, a spatial correlation analysis was performed using the higherresolution Meteoswiss gridded data. Figure 10a shows significant correlations of Fiescherhorn accumulation with precipitation in regions extending from the southwest to the northeast $(0.3<r<0.5)$. However, this was found only when introducing an offset of -1 year as discussed in Sect. 3.2.1. The observed pattern gets more pronounced when considering the period 1961-1977 (not shown) for which the highest correlation was found (see Table 2). We investigated whether the latter precipitation regime is reflected in the spatial correlations with the nearby northern station (Grimsel Hospiz). We found that the annual station precipitation is strongly correlated with almost the entire Swiss area except Ticino (Fig. 10b). A similar correlation pattern was found for Interlaken (not shown).

For Grenzgletscher, despite the considerable intraseasonal to interannual variability of precipitation (Fig. 9d) a good correlation with the instrumental data was observed (Fig. 10c). The most significant results $(0.4<r<0.8)$ found over Ticino, southern Alps, and northwestern Switzerland are consistent with the expected spatial pattern over the region. 

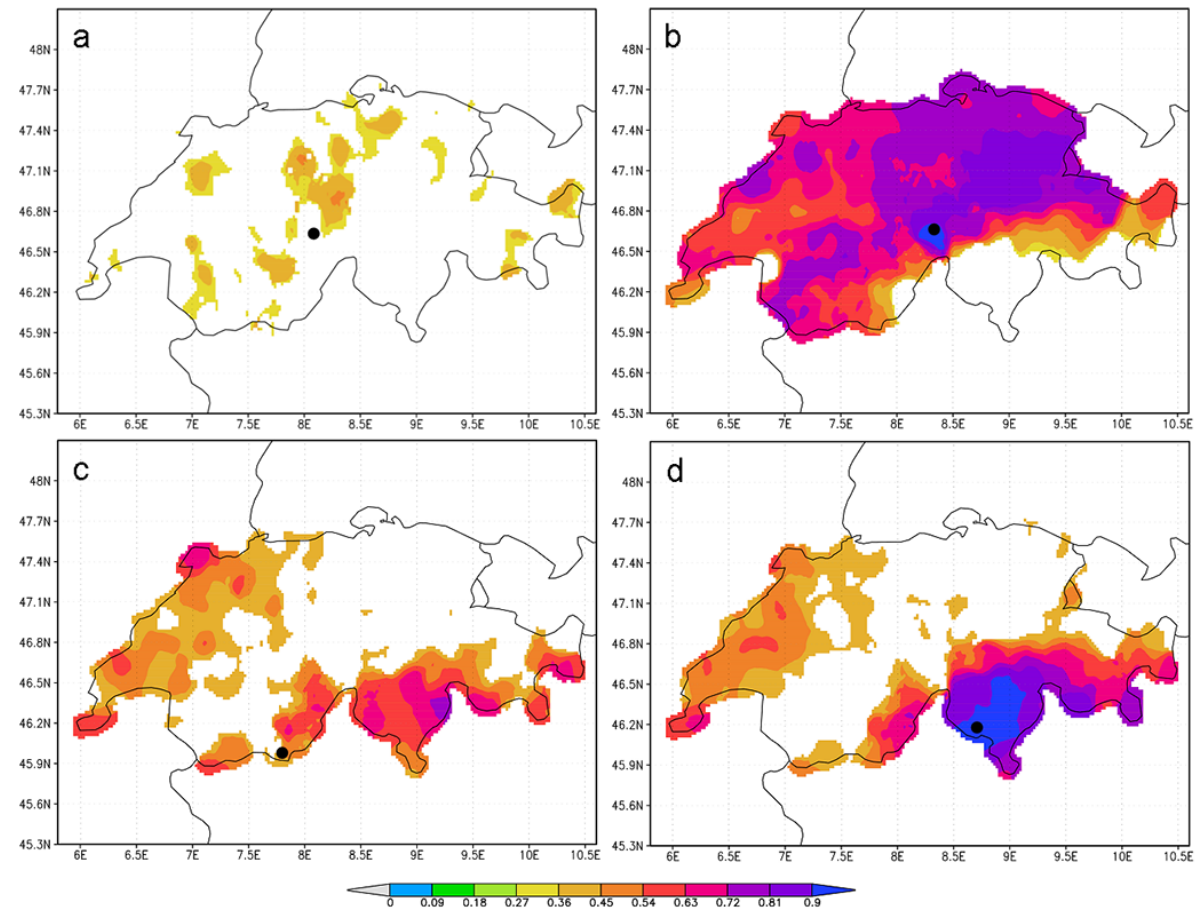

Figure 10. Spatial correlation map of annual records with the Meteoswiss gridded precipitation for northern Alpine (upper panels, period 1961-2001) and southern Alpine sites (lower panels, period 1961-1993, 1968-1970 excluded). Correlation with (a) Fiescherhorn annual net accumulation (where an offset of -1 year was introduced), (b) Grimsel Hospiz annual precipitation, (c) Grenzgletscher annual net accumulation, (d) Locarno annual precipitation. Black dots indicate the location of the sites. Areas with correlation coefficients statistically significant at the $5 \%$ level are shaded.

No uniform correlations were obtained nearby the Grenzgletscher region. This may be explained by the sparseness of the weather stations especially at such high altitudes, resulting in less accurate precipitation interpolation in the gridded data. In an analogue approach the correlation of the southern Alpine station precipitation data from Locarno with the gridded data gave very similar results, confirming the Grenzgletscher to be representative for southern Alpine precipitation (Fig. 10d). These results confirm that the two selected ice core sites represent different precipitation regimes.

\section{Conclusions and implications}

The study conducted with two Alpine ice cores has important implications on the way that temperature and precipitation from high-Alpine sites should be reconstructed in order to prevent over-interpretation, or even faulty interpretation of the records.

1. The seasonal cycle strongly affects the correlation of the isotopic signal with temperature, with the fraction of variance explained being $\sim 60 \%$ and decreasing to $0-10 \%$ when removing the seasonality. Accordingly, the GNIP stations showed a decrease in the fraction of variance explained from $\sim 70 \%$ to $10-20 \%$ indicating that over the Alpine area the seasonal temperature is only partially recorded in the $\delta^{18} \mathrm{O}$ and additional factors such as changes in the moisture sources and belowcloud processes have a significant impact on the isotopic signal. Ice core data may further be affected by postdepositional effects.

2. On an annual scale the high variability of precipitation, especially at high-altitude sites, might considerably bias the isotopic signal toward the season with more precipitation. For a glacier site with homogeneously preserved accumulation throughout the year the mean temperature signal is partly preserved on the annual scale. In the case of strong intraseasonal precipitation variability the annual mean of $\delta^{18} \mathrm{O}$ is only representative for temperature during precipitation and not for annual mean temperature. For such a glacier site, a paleotemperature reconstruction is not feasible.

3. Even for glacier sites in close proximity (only $60 \mathrm{~km}$ ) within the same mountain range, distinct local precipitation patterns can result in variations in how the temperature proxy signal is preserved. Thus, a careful individual calibration of the local $\delta^{18} \mathrm{O} / T$ relation is essential for every ice core site. 
4. The precipitation reconstruction from accumulation is critical, since it is more sensitive to post-depositional processes such as wind erosion and to initial layer assignment than the intrinsic core parameters like the $\delta^{18} \mathrm{O}$. Further, precipitation at a high-Alpine glacier may reflect very local conditions not captured in weather data obtained at lower elevation stations. Nevertheless, the distinct precipitation regimes for the northern and southern sites were observed in the respective accumulation records. At the Grenzgletscher the typical southern Alpine precipitation pattern was obtained in agreement with the southern Alpine stations.

5. Even for high-resolution ice core records with a pronounced seasonal signal, the dating uncertainty is rarely below \pm 1 year and cannot be neglected. The dating uncertainty cannot be overcome but its influence can be minimized by averaging or smoothing of the annual data still allowing for valuable ice core based temperature or precipitation reconstructions of the past climate.

Acknowledgements. This work was supported by the NCCR Climate programme of the SNF (VITA and PALVAREX projects). Meteoswiss is acknowledged for the station and gridded data. Support for the Twentieth Century Reanalysis Project data set is provided by the US Department of Energy, Office of Science Innovative and Novel Computational Impact on Theory and Experiment (DOE INCITE) programme, and Office of Biological and Environmental Research (BER), and by the National Oceanic and Atmospheric Administration Climate Program Office. ERA40 reanalysis data are provided by the European Centre for Medium-Range Weather Forecasts, Reading, UK (http://www.ecmwf.int/). NCEP Reanalysis data are provided by the NOAA/OAR/ESRL PSD, Boulder, CO, USA, from their Web site at http://www.cdc.noaa.gov/. We acknowledge the IAEA/WMO and the Swiss Geological Survey at the Federal Office for Water and Geology for giving access to the GNIP data.

We thank Anne Palmer for analysing part of the Fiescherhorn ice core.

We dedicate this study to the memory of Alexander Zapf, our colleague recently deceased in the mountains, with whom we shared fruitful discussions.

Edited by: A. N. LeGrande

\section{References}

Appenzeller, C., Begert, M., Zenklusen, E., and Scherrer, S. C.: Monitoring climate at Jungfraujoch in the high Swiss Alpine region, Sci. Total Environ., 391, 262-268, doi:10.1016/j.scitotenv.2007.10.005, 2008.

Araguás-Araguás, L., Fröhlich, K., and Rozanski, K.: Deuterium and oxygen-18 isotope composition of precipitation and atmospheric moisture, Hydrol. Process., 14, 13411355, doi:10.1002/1099-1085(20000615)14:8<1341::AIDHYP983>3.0.CO;2-Z, 2000.
Barry, R. G.: Mountain Weather and Climate, 3rd Edn., Cambridge University Press, 386-397, 2008.

Bohleber, P., Wagenbach, D., and Schöner, W.: To what extent do water isotope records from low accumulation Alpine ice cores reproduce instrumental temperature series?, Tellus B, 65, 20148, doi:10.3402/tellusb.v65i0.20148, 2013.

Bradley, R. S.: Paleoclimatology: Reconstructing Climates of the Quaternary, in: International Geophysics Series, 64, edited by: Dmowska, R. and Holton J. R., Academic Press, San Diego, California, 1999.

Brönnimann, S., Mariani, I., Schwikowski, M., Auchmann, R., and Eichler, A.: Simulating the temperature and precipitation signal in an Alpine ice core, Clim. Past, 9, 2013-2022, doi:10.5194/cp9-2013-2013, 2013.

Casado, M., Ortega, P., Masson-Delmotte, V., Risi, C., Swingedouw, D., Daux, V., Genty, D., Maignan, F., Solomina, O., Vinther, B., Viovy, N., and Yiou, P.: Impact of precipitation intermittency on NAO-temperature signals in proxy records, Clim. Past, 9, 871-886, doi:10.5194/cp-9-871-2013, 2013.

Ciais, P. and Jouzel, J.: Deuterium and oxygen 18 in precipitation: isotopic model, including mixed cloud processes, J. Geophys. Res., 99, 16793-16803, doi:10.1029/94JD00412, 1994.

Compo, G. P., Whitaker, J. S., Sardeshmukh, P. D., Matsui, N., Allan, R. J., Yin, X., Gleason, B. E., Vose, R. S., Rutledge, G., Bessemoulin, P., Brönnimann, S., Brunet, M., Crouthamel, R. I., Grant, A. N., Groisman, P. Y., Jones, P. D., Kruk, M., Kruger, A. C., Marshall, G. J., Maugeri, M., Mok, H. Y., Nordli, Ø., Ross, T. F., Trigo, R. M., Wang, X. L., Woodruff, S. D., and Worley, S. J.: The Twentieth Century Reanalysis Project, Q. J. Roy. Meteorol. Soc., 137, 1-28, doi:10.1002/qj.776, 2011.

Conroy, J. L., Cobb, K. M., and Noone, D.: Comparison of precipitation isotope variability across the tropical Pacific in observations and SWING2 model simulations, J. Geophys. Res.-Atmos., 5867-5892, doi:10.1002/jgrd.50412, 2013.

Craig, H.: Isotopic variations in meteoric waters, Science, 133, 1702-1703, doi:10.1126/science.133.3465.1702, 1961.

Cuffey, K. and Paterson, W. S. B.: Ice core studies, in: The physics of the glaciers, 4th Edn., Elsevier, Butterworth-Heinemann, USA, 611-674, 2010.

Dansgaard, W.: Stable isotopes in precipitation, Tellus, 16, 436468, doi:10.1111/j.2153-3490.1964.tb00181.x, 1964.

Dansgaard, W. and Johnsen, S. J.: A flow model and a time scale for the ice core from Camp Century, Greenland, J. Glaciol., 846 , 215-223, 1969.

Eichler, A., Schwikowski, M., Gäggeler, H. W., Furrer, V., Synal, H.-A., Beer, J., Saurer, M., and Funk, M.: Glaciochemical dating of an ice core from upper Grenzgletscher (4200 ma.s.1.), J. Glaciol., 46, 507-515, doi:10.3189/172756500781833098, 2000.

Eichler, A., Schwikoski, M., and Gäggeler, H. W.: Meltwaterinduced relocation of chemical species in Alpine firn, Tellus B, 53, 192-203, doi:10.1034/j.1600-0889.2001.d01-15.x, 2001.

Eichler, A., Schwikowski, M., Furger, M., Schotterer, U., and Gäggeler, H. W.: Sources and distribution of trace species in Alpine precipitation inferred from two 60-year ice core paleorecords, Atmos. Chem. Phys. Discuss., 4, 71-108, doi:10.5194/acpd-4-71-2004, 2004. 
Field, R. D., Jones, D. B. A., and Brown, D. P.: Effects of postcondensation exchange on the isotopic composition of water in the atmosphere, J. Geophys. Res.-Atmos., 115, D24305, doi:10.1029/2010JD014334, 2010.

Frei, C. and Schär, C.: A precipitation climatology of the Alps from high-resolution rain-gauge observations, Int. J. Climatol., 18, 873-900, doi:10.1002/(SICI)10970088(19980630)18:8<873::AID-JOC255>3.0.CO;2-9, 1998.

Friedman, I., Machta, L., and Soller, R.: Water-vapor exchange between a water droplet and its environment, J. Geophys. Res., 67, 2761-2766, doi:10.1029/JZ067i007p02761, 1962.

Gat, J. R.: Oxygen and hydrogen isotopes in the hydrologic cycle, Annu. Rev. Earth Ol. Sc., 24, 225-262, doi:10.1146/annurev.earth.24.1.225, 1996.

Hammer, C. U., Clausen, H. B., Dansgaard, W., Gundestrup, N., Johnsen, S. J., and Reeh, N.: Dating of Greenland ice cores by flow models, isotopes, volcanic debris, and continental dust, J. Glaciol., 20, 3-26, 1978.

Henderson, K., Laube, A., Gäggeler, H. W., Olivier, S., Papina, T., and Schwikowski, M.: Temporal variations of accumulation and temperature during the past two centuries from Belukha ice core, Siberian Altai, J. Geophys. Res., 111, D03104, doi:10.1029/2005JD005819, 2006.

Herren, P.-A., Eichler, A., Machguth, H., Papina, T., Tobler, L., Zapf, A., and Schwikowski, M.: The onset of Neoglaciation 6000 years ago in western Mongolia revealed by an ice core from the Tsambagarav mountain range, Quaternary Sci. Rev., 69, 5968, doi:10.1016/j.quascirev.2013.02.025, 2013.

IAEA/WMO: Global Network of Isotopes in Precipitation, The GNIP Database, accessible at: http://www.iaea.org/water, last access: 31 August 2013.

Jenk, T. M.: Ice core based reconstruction of past climate conditions and air pollution in the Alps using radiocarbon, Ph.D. thesis, Department of Chemistry and Biochemistry, University of Bern, Bern, Switzerland, 165 pp., 2006.

Johnsen, S. J.: Stable isotope homogenization of polar firn and ice, Proc. Symp. on Isotopes and Impurities in Snow and Ice, I.U.G.G. XVI, General Assembly, Grenoble Aug. Sept. 1975, Washington, 15, 210-219, 1977.

Johnsen, S. J., Clausen, H. B., Cuffey, K. M., Hoffmann, G., Schwander, J., and Creyts, T.: Diffusion of stable isotopes in polar firn and ice: the isotope effect in firn diffusion, in: Physics of Ice Core Records, edited by: Hondoh, T., Hokkaido University Press, Sapporo, 2000.

Jouzel, J.: Water stable isotopes: Atmospheric composition and applications in polar ice core studies, in: Treatise on geochemistry, vol. 4, Elsevier, New York, 213-243, 2003.

Jouzel, J. and Souchez, R. A.: Melting-refreezing at the glacier sole and the isotopic composition of the ice, J. Glaciol., 28, 35-42, 1982.

Jouzel, J. and Merlivat, L.: Deuterium and oxygen 18 in precipitation: modeling of the isotopic effects during snow formation, J. Geophys. Res., 89, 11749-11757, doi:10.1029/JD089iD07p11749, 1984.

Jouzel, J., Alley, R. B., Cuffey, K. M., Dansgaard, W., Grootes, P., Hoffmann, G., Johnsen, S. J., Koster, R. D., Peel, D., Shuman, C. A., Stievenard, M., Stuiver, M., and White, J.: Validity of the temperature reconstruction from water isotopes in ice cores, J. Geophys. Res.-Oceans, 102, 26471-26487, doi:10.1029/97JC01283, 1997a.

Jouzel, J., Fröhlich, K., and Schotterer, U.: Deuterium and oxygen18 in present-day precipitation: data and modelling, Hydrolog. Sci. J., 42, 747-763, doi:10.1080/02626669709492070, 1997b.

Jouzel, J., Hoffmann, G., Koster, R. D., and Masson, V.: Water isotopes in precipitation: data/model comparison for presentday and past climates, Quaternry Sci. Rev., 19, 363-379, doi:10.1016/S0277-3791(99)00069-4, 2000.

Kalnay, E., Kanamitsu, M., Kistler, R., Collins, W., Deaven, D., Gandin, L., Iredell, M., Saha, S., White, G., Woollen, J., Zhu, Y., Leetmaa, A., Reynolds, R., Chelliah, M., Ebisuzaki, W., Higgins, W., Janowiak, J., Mo, K. C., Ropelewski, C., Wang, J., Jenne, R., and Joseph, D.: The NCEP/NCAR 40-Year Reanalysis Project, B. Am. Meteorol. Soc., 77, 437-471, 1996.

Kohn, M. J. and Welker, J. M.: On the temperature correlation of $\delta^{18} \mathrm{O}$ in modern precipitation, Earth Planet. Sc. Lett., 231, 8796, doi:10.1016/j.eps1.2004.12.004, 2005.

Liu, J., Fu, G., Song, X., Charles, S. P., Zhang, Y., Han, D., and Wang, S.: Stable isotopic compositions in Australian precipitation, J. Geophys. Res.-Atmos, 115, D23307, doi:10.1029/2010JD014403, 2010.

Meteoswiss: Documentation of MeteoSwiss Grid-Data Products - Monthly and Yearly Precipitation: RhiresM and RhiresY, accessible at: http://www.meteosuisse.admin.ch/web/de/services/ datenportal/gitterdaten/precip/RhiresM.Par.0006.DownloadFile. tmp/proddocrhiresm.pdf, last access: 31 August 2013.

Noone, D. and Sturm, C.: Comprehensive Dynamical Models of Global and Regional Water Isotope Distributions, in: Isoscapes, edited by: West, J. B., Bowen, G. J., Dawson, T. E., and Tu, K. P., Springer, Netherlands, 195-219, 2010.

Nye, J. F.: Correction factor for accumulation measured by the thickness of the annual layers in an ice sheet, J. Glaciol., 4, 785788, 1963.

Persson, A., Langen, P. L., Ditlevsen, P., and Vinther, B. M.: The influence of precipitation weighting on interannual variability of stable water isotopes in Greenland, J. Geophys. Res., 116, D20120, doi:10.1029/2010JD015517, 2011.

Risi, C., Bony, S., and Vimeux, F.: Influence of convective processes on the isotopic composition $\left(\delta^{18} \mathrm{O}\right.$ and $\left.\delta \mathrm{D}\right)$ of precipitation and water vapor in the tropics: 2 . Physical interpretation of the amount effect, J. Geophys. Res.-Atmos., 113, D19306, doi:10.1029/2008JD009943, 2008.

Rozanski, K., Araguas-Araguas, L., and Gonfiantini, R.: Relation between long-term trends of oxygen-18 isotope composition of precipitation and climate, Science, 258, 981-985, doi:10.1126/science.258.5084.981, 1992.

Rozanski, K., Araguas-Araguas, L., and Gonfiantini, R.: Isotopic patterns in modern global precipitation, Geophys. Monogr., 78, 1-36, 1993.

Rozanski, K., Johnsen, S. J., Schotterer, U., and Thompson, L. G.: Reconstruction of past climates from stable isotope records of palaeo-precipitation preserved in continental archives, Hydrolog. Sci. J., 42, 725-745, doi:10.1080/02626669709492069, 1997.

Saurer, M., Kress, A., Leuenberger, M., Rinne, K. T., Treydte, K. S., and Siegwolf, R. T. W.: Influence of atmospheric circulation patterns on the oxygen isotope ratio of tree rings in the Alpine region, J. Geophys. Res.-Atmos., 117, D05118, doi:10.1029/2011JD016861, 2012. 
Schoener, W., Auer, I., Bohm, R., Keck, L., and Wagenbach, D.: Spatial representativity of air-temperature information from instrumental and ice-core-based isotope records in the European Alps, Ann. Glaciol., 35, 157-161, doi:10.3189/172756402781816717, 2002.

Schotterer, U., Oeschger, H., Wagenbach, D., and Münnich, K. O.: Information on paleo-precipitation on a high altitude glacier Monte Rosa, Switzerland, Z. Gletscherk. Glazialgeol., 21, 379$388,1985$.

Schotterer, U., Fröhlich, K., Gäggeler, H. W., Sandjordj, S., and Stichler, W.: Isotope records from Mongolian and Alpine ice cores as climate indicators, Climatic Change, 36, 519-530, doi:10.1023/A:1005338427567, 1997.

Schotterer, U., Stichler, W., Graf, W., Bürki, H. U., Gourcey, L., Ginot, P., and Huber, T.: Stable isotopes in alpine ice cores: do they record climate variability?, in: Proc. of an International Symposium on the Study of Environmental Change using Isotope Techniques, 23-27 April 2001, IAEA, Vienna, 2002.

Schotterer, U., Stichler, W., and Ginot, P.: The influence of postdepositional effects on ice core studies: examples from the Alps, Andes, and Alta1, in: Earth Paleoenvironments: Records preserved in Mid- and Low-Latitude Glaciers, edited by: De Wayne Ceciel, L., Green, J. R., and Thompson, L. G., Developments in Paleoenvironmental Research Series, Kluwer Academic Publishers, London, 39-60, 2004.

Schürch, M., Kozel, R., Schotterer, U., and Tripet, J.-P.: Observation of isotopes in the water cycle - the Swiss National Network (NISOT), Environ. Geol., 45, 1-11, doi:10.1007/s00254003-0843-9, 2003.

Schwerzmann, A., Funk, M., Blatter, H., Lüthi, M., Schwikowski, M., and Palmer, A.: A method to reconstruct past accumulation rates in alpine firn regions: A study on Fiescherhorn, Swiss Alps, J. Geophys. Res., 111, F01014, doi:10.1029/2005JF000283, 2006.

Schwikowski, M., Seibert, P., Baltensperger, U., and Gaggeler, H. W.: A study of an outstanding Saharan dust event at the high-alpine site Jungfraujoch, Switzerland, Atmos. Environ., 29, 1829-1842, doi:10.1016/1352-2310(95)00060-C, 1995.

Schwikowski, M., Brütsch, S., Gäggeler, H. W., and Schotterer, U.: A high-resolution air chemistry record from an Alpine ice core: Fiescherhorn glacier, Swiss Alps, J. Geophys. Res., 104, 13709 13719, doi:10.1029/1998JD100112, 1999.

Schwikowski, M., Barbante, C., Doering, T., Gaeggeler, H. W., Boutron, C., Schotterer, U., Tobler, L., Van de Velde, K., Ferrari, C., Cozzi, G., Rosman, K., and Cescon, P.: Post-17thcentury changes of European lead emissions recorded in highaltitude alpine snow and ice, Environ. Sci. Technol., 38, 957964, doi:10.1021/es034715o, 2004.
Seibert, D. P.: South foehn studies since the ALPEX experiment, Meteorol. Atmos. Phys., 43, 91-103, doi:10.1007/BF01028112, 1990.

Siegenthaler, U. and Oeschger, H.: Correlation of ${ }^{18} \mathrm{O}$ in precipitation with temperature and altitude, Nature, 285, 314-317, doi:10.1038/285314a0, 1980.

Sigl, M.: Ice core based reconstruction of past climate conditions from Colle Gnifetti, Swiss Alps, Ph.D. thesis, Department of Chemistry and Biochemistry, University of Bern, Bern, Switzerland, 200 pp., 2009.

Sodemann, H. and Zubler E.: Seasonal and inter-annual variability of the moisture sources for Alpine precipitation during 19952002, Int. J. Climatol., 30, 947-961, doi:10.1002/joc.1932, 2009.

Stichler, W. and Schotterer, U.: From accumulation to discharge: modification of stable isotopes during glacial and post-glacial processes, Hydrol. Process., 14, 1423-1438, doi:10.1002/10991085(20000615)14:8<1423::AID-HYP991>3.0.CO;2-X, 2000.

Stichler, W., Schotterer, U., Fröhlich, K., Ginot, P., Kull, C., Gäggeler, H., and Pouyaud, B.: Influence of sublimation on stable isotope records recovered from high-altitude glaciers in the tropical Andes, J. Geophys. Res.-Atmos., 106, 22613-22620, doi:10.1029/2001JD900179, 2001.

Sturm, C., Zhang, Q., and Noone, D.: An introduction to stable water isotopes in climate models: benefits of forward proxy modelling for paleoclimatology, Clim. Past, 6, 115-129, doi:10.5194/cp-6-115-2010, 2010.

Trouet, V. and Van Oldenborgh, G. J.: KNMI Climate Explorer: A Web-Based Research Tool for High-Resolution Paleoclimatology, Tree-Ring Res., 69, 3-13, doi:10.3959/1536-1098-69.1.3, 2013.

Uppala, S. M., Kallberg, P. W., Simmons, A. J., Andrae, U., Bechtold, V. D., Fiorino, M., Gibson, J. K., Haseler, J., Hernandez, A., Kelly, G. A., Li, X., Onogi, K., Saarinen, S., Sokka, N., Allan, R. P., Andersson, E., Arpe, K., Balmaseda, M. A., Beljaars, A. C. M., Van De Berg, L., Bidlot, J., Bormann, N., Caires, S., Chevallier, F., Dethof, A., Dragosavac, M., Fisher, M., Fuentes, M., Hagemann, S., Holm, E., Hoskins, B. J., Isaksen, L., Janssen, P. A. E. M., Jenne, R., McNally, A. P., Mahfouf, J. F., Morcrette, J. J., Rayner, N. A., Saunders, R. W., Simon, P., Sterl, A., Trenberth, K. E., Untch, A., Vasiljevic, D., Viterbo, P., and Woollen, J.: The ERA-40 re-analysis, Q. J. Roy. Meteorol. Soc., 131, 2961-3012, 2005.

Wagenbach, D., Münnich, K. O., Schotterer, U., and Oeschger, H.: The anthropogenic impact on snow chemistry at Colle Gnifetti, Swiss Alps, Ann. Glaciol., 10, 183-187, 1988.

Yurtsever, Y. and Gat, J. R.: Atmospheric waters, in: Stable Isotope Hydrology: Deuterium and Oxygen-18 in the Water Cycle, edited by: Gat, J. R. and Gonfiantini, R., Tech. Rep. Ser. 210, Int. At. Energy Agency, Vienna, 103-142, 1981. 